\title{
Management control systems in innovation companies: A literature based framework
}

\begin{abstract}
Past research has traditionally argued that management control systems (MCSs) may present a hindrance to the creativity of innovation companies. This theoretical paper surveys the literature to focus an investigation on the MCSs of innovation companies. Within the object of control paradigm the paper develops and presents a theoretical model of the impact of eleven external, organisational and innovation related contingency factors on the MCSs in companies that engage in innovation activities. We also suggest measures for further empirical research. By formulating hypotheses on 43 potential interactions the model predicts contradictory influences on two direct control categories, results and action control, but stresses the importance of two indirect categories, personnel and cultural control. More specifically, the high levels of technological complexity and innovation capability in this type of company are expected to be negatively associated with the application of results and action control, whereas personnel and cultural seem to be more appropriate. Furthermore, important sources of finance, venture capital and public funding, are both hypothesised to be positively associated with the application of results, action and personnel control; whereas only public funding is predicted to be positively related to the application of cultural control. The principal contribution of this paper lies in synthesising the literature to provide a model of the impact of a unique set of eleven contingency factors for innovation companies on a broad scope of controls. In addition, the contingency model, if empirically validated, would add value by inferring the particular forms of management control which would be beneficial in innovative company settings.
\end{abstract}

Keywords: management control systems, innovation companies, contingency model, organisational maturity, venture capital, public funding

\section{Introduction}

This paper aims to develop a testable model, based on a systematic literature review ${ }^{1}$, of the relationship between a broad set of contingency factors and the application of management control systems (MCSs) in innovation companies. The definition of innovation companies is based on the OECD's (2005, p. 59) understanding of the 'innovation-active firm': “firms that have had innovation activities during the period under review, regardless of whether the

1 Mainly the framework is literature based; however some hypotheses are supplemented by observations from preliminary fieldwork (see Section 2.2). 
activity resulted in the implementation of an innovation". ${ }^{2}$ As this definition might be too broad and could describe many medium-sized and large-sized companies, a further requirement for the identification of an innovation company could be that these "innovationactive firms" need to be actively involved in research projects with other partners e.g. by being part of an innovation cluster. Research shows that companies that are part of a cluster tend to be more innovative and have higher growth rates than other companies in the same industry (e.g. Baptista and Swann 1998; Beaudry and Breschi 2003; Enright 2003). The focus of innovation collaboration would also comply with this framework's understanding of “innovation capability” (see Section 2.2.3). The term innovation covers the introduction of a "good or service that is new or significantly improved with respect to its characteristics or intended use" (product innovation, OECD 2005, p. 49), the implementation of a "new or significantly improved production or delivery method" including "significant changes in techniques, equipment and/or software” (process innovation, OECD 2005, p. 50), "new marketing method involving significant changes in product design or packaging, product placement, product promotion or pricing” (marketing innovation, OECD 2005, p. 50) or “new organisational method in the firm's business practices, workplace organisation or external relations” (organisational innovation, OECD 2005, p. 52). Innovativeness is understood as "the notion of openness to new ideas as an aspect of a firm's culture" serving as a "measure of the organization's orientation toward innovation” (Hurley and Hult 1998, p. 44).

The literature is equivocal about the appropriateness of MCSs to innovation companies because these companies have specific requirements concerning their control systems. On the one hand, it is argued that such companies struggle to balance their need for control and the attempt to maintain creativity for generating innovations (e.g. Amabile 1998; Lukka and Granlund 2003). Pioneering studies in small and non-complex companies emphasised the role of informal and loose structures in particular in order to enhance innovativeness (Burns and Stalker 1961; Lawrence and Lorsch 1967). On the other hand, more recent research has stressed the role that specific types of MCSs can play, even in highly innovative companies (e.g. Bart 1993; Abernethy and Brownell 1997; Nixon 1998; Davila 2000; Cardinal 2001; Davila et al. 2009). In addition, in companies with high knowledge intensity and enhanced needs for organisational learning, management controls were found useful if developed to

\footnotetext{
${ }^{2}$ In this context, innovation activities encompass "all scientific, technological, organisational, financial and commercial steps which actually, or are intended to, lead to the implementation of innovations" and also include "R\&D that is not directly related to the development of a scientific innovation" (OECD 2005, p. 47).
} 
address the needs of their professionals (Alvesson 1993b; Kloot 1997; Ditillo 2004; Chenhall 2005).

In order to derive a broad insight into the application of MCS in innovation companies, we adopt a contingency theory approach. Contingency theory is based on the view that there is no one-best MCS for all companies, but that systems should be contingent on the circumstances a company faces (Otley 1980). To provide a structured understanding of the MCSs used in innovation companies, eleven contingency factors from three categories, namely external, organisational and innovation related, are identified from a systematic literature review and a preliminary qualitative study. As the aim is not to investigate single MCS instruments, the Merchant and Van der Stede (2012) framework with its comprehensive picture of MCSs, distinguishing between results, action, personnel and cultural controls, has been adopted. The following figure depicts the contingency variables and potential relationships, positive or negative, with the use of each of the four MCS categories.

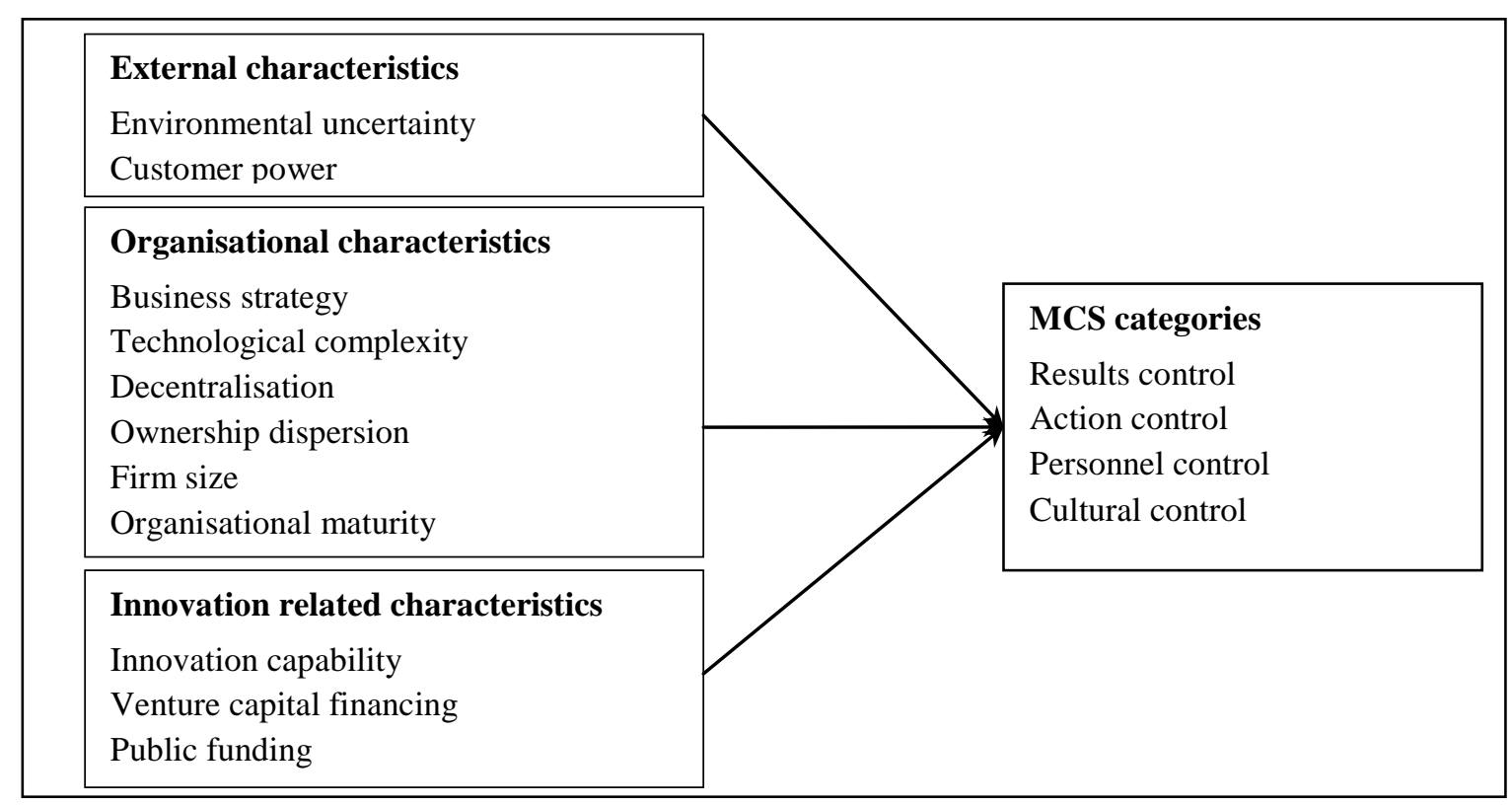

Fig 1. Innovation companies' characteristics and their relationships with MCS categories

Although the application of MCSs in innovative settings has been addressed in numerous studies, the literature is fragmented discussing different single control instruments or individual control categories and only a few contingency factors that are expected to be relevant to innovation companies. The contribution of this paper lies in a systematic synthesis of the MCS literature concerning innovative settings and the identification of contingency factors that are expected to be influential in designing the MCSs in these companies. In contrast to only discussing single instruments or specific categories, our paper considers the application of broad categories of control based on the object of control framework (Merchant 
and Van der Stede 2012). A variety of authors recommend the application of a more comprehensive and integrative approach, as studies investigating single instruments or a limited number of components of control systems have led to unclear findings or conflicting results (e.g. Otley 1999; Merchant and Otley 2007; Ferreira and Otley 2009). In particular, besides direct control categories, also the relevance of indirect controls for innovation companies is addressed.

Through a literature review and a preliminary qualitative study, eleven contingency factors were identified that are expected to be relevant for the given context. MCSs in innovation companies are influenced by traditional contingency factors, in categories of external and organisational characteristics. In addition, the expected influence of three specifically innovation related contingency factors on the control categories is hypothesised. Discussing only the innovation related contingency factors would not account for the various influential factors that innovation companies are confronted with when designing their MCSs. The paper aims to put the framework into academic discussion and to shed light on the dispersed literature of contingency-based MCS literature in innovation settings.

The aim of this paper is to develop a testable model, based on a systematic literature review and a preliminary qualitative study; Section 2 introduces the framework and the contingency factors adopted. In Section 3 the hypotheses are developed, while the final section provides a summary and conclusion.

\section{Theoretical framework}

In this section management control systems with their different frameworks are presented by first explaining the framework chosen for this paper. The second part refers to contingency theory and the contingency factors to be included.

\subsection{Management control systems}

MCSs are defined as "all the devices or systems managers use to ensure that the behaviors and decisions of their employees are consistent with the organization's objectives and strategies” (Merchant and Van der Stede 2012, p. 6). Within the context of innovation companies this research strives to investigate the entire MCS of companies rather than single instruments or controls. This responds to Davila (2000, p. 404): “researching management control systems in new product development cannot be restricted to traditional accounting measures, but needs to encompass a broader set of measures.” 
Building on Hutzschenreuter (2009), this study distinguishes between direct and indirect modes of control based on the degree of interaction with employees. Originally, this differentiation goes back to Jaworski (1988, p. 26) who used the terms 'formal control' for “written, management-initiated mechanisms” and 'informal control' for “unwritten, typically worker-initiated mechanisms”. In order to avoid any misunderstandings with Jaworski's understanding of formal control and as some techniques of personnel and cultural control are typically also written and initiated by the management, this study follows Hutzschenreuter's direct-indirect dichotomy. Similarly, Adami (1999, p. 133) uses this differentiation where direct control includes “direct supervision over those performing tasks, quality control, designation of authorization responsibilities, standard operating procedures, rules, and budget and expenditure guidelines”, whereas indirect control encompasses “job descriptions, culture, performance appraisals, career advancement, incentives, compensation and remuneration, training and skill development, and the existence of flexible work arrangements” ${ }^{\text {}}$. Hence our framework focuses on formal MCSs, i.e. controls that have been consciously developed and implemented by the organisation's management, and distinguishes these controls by the degree of interaction with employees into direct and indirect modes of control.

Different conceptualisations of MCSs have been developed during recent decades ${ }^{4}$ of which some of the most influential frameworks are summarized in the figure below distinguishing between direct and indirect modes of control.

\footnotetext{
3 In our framework, performance appraisals are part of results control and therefore seen as direct control, due to the direct interaction between management and employee.

4 For a review of conceptualisations of MCS see, for example, Strauß and Zecher (2012).
} 


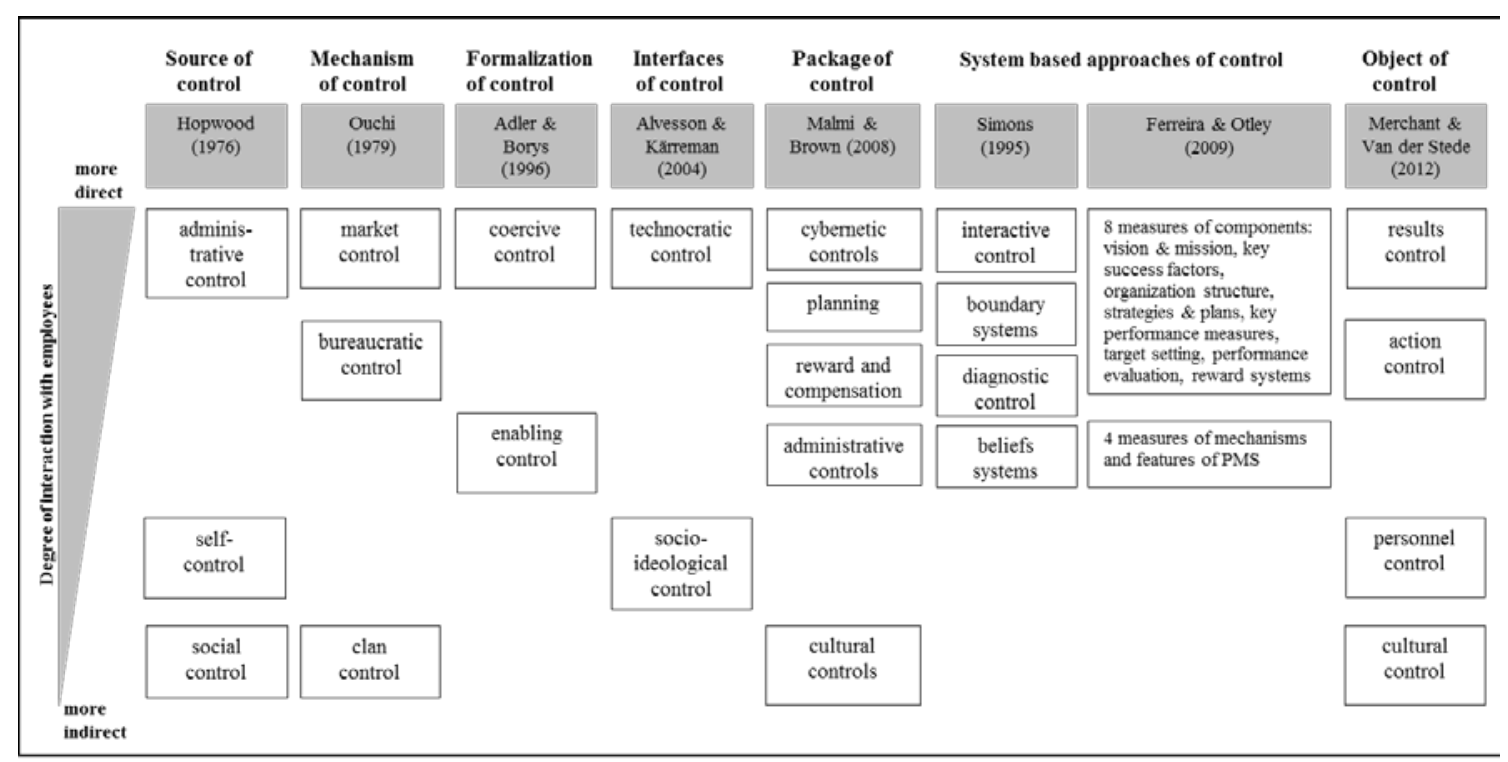

Fig. 2 Overview of MCS frameworks (adapted from Hutzschenreuter 2009)

Hopwood (1976) and Ouchi (1979) were among the first to consider socialization processes as a type of control which they named social control and clan control, respectively. However, these were described as informal controls, evolving without explicit influence by the organisation's management. Additionally, Hopwood (1976) describes a type of control that has to be internalized by employees, self-control, that basically allows administrative control to be effective. Alvesson and Kärreman (2004, p. 426) developed the concept of 'socio-ideological control' defined as "efforts to persuade people to adapt to certain values, norms and ideas about what is good, important, praiseworthy, etc. in terms of work and organizational life". It is based on the idea of clan control, but being initiated by the management, it is a formal type of control. The concept of coercive and enabling bureaucracies (Adler and Borys 1996) also contributed to the development of MCS categories. In this context coercive controls "are designed to force reluctant compliance and to extract recalcitrant effort” (Adler and Borys 1996, p. 69). Enabling control contains more indirect meta-routines or meta-structures (Jørgensen and Messner 2009) generating "procedures that facilitate responses to real work contingencies" by providing "users with visibility into the processes they regulate by explicating its key components by codifying best-practice routines” (Adler and Borys 1996, pp. 71 f.).

The 'package of controls' framework of Malmi and Brown (2008) acknowledges that organisations tend to apply very complex systems of control. Their comprehensive model consists of five control types and stresses the importance of informal control, criticizing that most studies focus on accounting or formal control in general. However, Malmi and Brown 
(2008) will not be followed in this paper as it "broadly maps the tools, systems and practices managers have available to formally and informally direct employee behaviour” (p. 295) and therefore represents a general view on control systems acting as a package. Furthermore, as many innovation companies are small-and-medium sized enterprises, the framework may contain elements that these enterprises are even not aware of. The Anthony and Govindarajan (2007) framework is not included in Figure 2 because it does not distinguish types of control, but develops steps of MCSs in a cybernetic framework. It mainly focuses on instruments of results control, but does not address personnel and cultural control.

Simons' (1995) levers of control framework, building on the different types of use of control, while explicitly focusing on formal control, does acknowledge the role of social and cultural aspects for control. In particular, interactive controls being defined as "formal information systems managers use to involve themselves regularly and personally in the decision activities of subordinates" (Simons 1995, p. 96) represent a very direct way of control. However, as Simons' (1995) framework concentrates on the use of MCSs rather than their design and on MCSs applied only by senior management it is not further considered in this paper.

The extended system-based framework of Ferreira and Otley (2009) is an elaboration of Otley (1999)'s earlier framework of performance measurement systems (PMSs) and incorporates twelve dimensions which include mainly formal control aspects. Of the proposed dimensions, eight relate to the core of the PMS and its components, hence to ends and means, and the other four concern enabling mechanism and features of the PMS. Furthermore the framework represents some aspects of the levers of control framework of Simons (1995). However, the Ferreira and Otley (2009) framework neglects social components as part of a control system.

Merchant and Van der Stede's (2012) object of control framework, classifies four categories of control, namely results, action, personnel and cultural control, of which each is initiated by the management and therefore is a formal type of control. For example, cultural control can be fostered by the management through development of codes of conduct, a mission statement, group-based rewards, as well as physical and social arrangements. The object of control framework also reflects concepts of the other frameworks. In Hopwood's (1976) framework, administrative control encompasses both results and action control; whereas in Ouchi's (1979) composition these two types of control can be implemented through bureaucratic and market control as well. The object of control framework also regards 
enabling control instruments such as employee selection and retention or codes of conduct (Merchant and Van der Stede 2012, p. 5).

Besides these Anglo-American frameworks which enjoy widespread use in MCS research, there are also MCSs frameworks with significance in other geographical and cultural contexts, e.g. the conceptualisation of 'controlling' in German-speaking countries (e.g. Guenther 2013). However as these frameworks are not written in English they are, as yet, relatively unfamiliar globally; hence, their application in this paper might hamper generalizability of the theoretical model.

The object of control framework of Merchant and Van der Stede (2012) is chosen for this paper as it regards results and action control as typical administrative and more direct types of control, but also more indirect types of control enabling employees to "control and motivate themselves” (personal control, p. 88) or to “encourage mutual monitoring” (cultural control, p. 90) through management-initiated control instruments. An overview of the four categories of control, their definition and examples of corresponding control techniques, is shown in the table below.

Table 1 Merchant and Van der Stede's (2012) object of control framework (adapted from Hutzschenreuter 2009)

\begin{tabular}{|c|c|c|c|c|}
\hline Category & Results control & Action control & Personnel control & Cultural control \\
\hline $\begin{array}{l}\text { Mode of } \\
\text { control }\end{array}$ & direct & direct & indirect & indirect \\
\hline Definition & $\begin{array}{l}\text { enforce target } \\
\text { achievement through } \\
\text { monitoring and } \\
\text { rewarding outputs }\end{array}$ & $\begin{array}{l}\text { prevention of } \\
\text { undesired behaviour, } \\
\text { promotion of desired } \\
\text { behaviour for task } \\
\text { accomplishment }\end{array}$ & $\begin{array}{l}\text { fulfilment of job } \\
\text { requirements }\end{array}$ & $\begin{array}{l}\text { control through } \\
\text { establishment of } \\
\text { shared values, social } \\
\text { norms and beliefs }\end{array}$ \\
\hline $\begin{array}{l}\text { Notion of } \\
\text { control }\end{array}$ & $\begin{array}{l}\text { control of outputs } \\
\text { through management }\end{array}$ & $\begin{array}{l}\text { control of behaviour } \\
\text { through management }\end{array}$ & $\begin{array}{l}\text { exercise of self- } \\
\text { control by individual } \\
\text { employees }\end{array}$ & $\begin{array}{l}\text { group control among } \\
\text { organisational } \\
\text { members }\end{array}$ \\
\hline $\begin{array}{l}\text { Examples of } \\
\text { control } \\
\text { techniques }\end{array}$ & $\begin{array}{l}\text { - performance } \\
\text { measurement (e.g. } \\
\text { ROE, net income, } \\
\text { inventory control, } \\
\text { quality) } \\
\text { - budgeting } \\
\text { - reward structures } \\
\text { - report of } \\
\text { achievements }\end{array}$ & $\begin{array}{l}\text { - procedure guide } \\
\text { - operating manuals } \\
\text { - supervision of rules } \\
\text { - physical or } \\
\text { administrative } \\
\text { restrictions (e.g. } \\
\text { expenditure } \\
\text { approvals, pass- } \\
\text { words) }\end{array}$ & $\begin{array}{l}\text { - recruitment policies } \\
\text { - training } \\
\text { programmes } \\
\text { - job design } \\
\text { - provision of } \\
\text { sufficient resources } \\
\text { for the job }\end{array}$ & $\begin{array}{l}\text { - codes of conduct } \\
\text { - group-based } \\
\text { rewards } \\
\text { - interaction } \\
\text { - manager serves as a } \\
\text { role model }\end{array}$ \\
\hline
\end{tabular}




\subsection{Contingency theory perspective}

Within a theoretical framework, this paper aims to elaborate which environmental and organisational factors influence the design of MCSs of innovation companies. It is motivated by the view that the MCSs of companies that do not pursue innovation activities are not suitable for those companies that are innovation active. Contingency theory denies universal applicability of MCSs, but argues that the applicability of management control is contingent on the situational factors that are faced by a company. There is no "best" management control system, but its design should be contingent on circumstances (Otley 1980). Therefore a contingency theory approach is adopted in order to provide a comprehensive picture of the specific characteristics that influence the adoption of the MCS categories in innovation companies.

Numerous contingency factors have been argued to be relevant for companies in general and innovation companies in particular. For this study, contingency factors have been identified from a systematic literature review. Given the breadth of literature on management, control, innovation and technology, this literature review was selective in nature and not exhaustive. This review concentrates on papers in major accounting and cognate journals ${ }^{5}$ (both research studies and literature reviews) that addressed contingent views on formal controls mainly in innovative company settings. ${ }^{6}$

In addition, in order to identify relevant additional contingency factors, interviews were conducted with managers of five innovation companies in Germany. These companies were selected from an innovation cluster initiative with a focus on the following fields: surface treatment, optics, medical technology and nanotechnology. The number of employees in the companies ranges between 16 and 180 employees (one being an affiliate of a company with 4,000 employees). The companies’ ages range between 9 and 20 years. Each of the interviews lasted about 90 minutes with the aim of clarifying how MCSs in these companies are used,

\footnotetext{
5 The literature review covered the 1980-2012 period in the journals Accounting, Organizations and Society and Management Accounting Research using the ScienceDirect database and the journals Accounting Horizons, Accounting Review and Administrative Science Quarterly using the EBSCO Business Source Premier database. The keywords for the search were "control” and "innovation” or "research and development” or "product development” or "network”. Of these, papers with a focus on innovation companies were selected. Further, journals with a focus on innovation and R\&D, namely R\&D Management (EBSCO Business Source Premier) and Technovation (ScienceDirect), were searched for “management control” or the related MCS categories.

6 For reviews of the contingency-based literature addressing MCSs see Chapman (1997), Langfield-Smith (1997), Hartmann (2000) and Chenhall (2003).
} 
what roles MCSs play for controlling innovation activities and what factors that influence the design of MCSs in these companies can be identified.

Contingency research has been criticised as being "piecemeal" (Fisher 1995) or “fragmentary” (Dent 1990) as many contingency-based studies only examine one contingency and one MCS component or characteristic at a time. Therefore Fisher suggests that "the ultimate goal of contingency control research should be to develop and test a comprehensive model that includes multiple control systems, multiple contingent variables, and multiple outcome variables” (1995, p. 24). The approach of this model is consistent with Fisher (1995) in that it addresses a variety of contingencies and a comprehensive model of MCS categories.

MCSs in innovation companies may be expected to be influenced both by contingency factors identified in the traditional control literature and by innovation related contingency factors. This paper is concerned with the likely impact of a set of eleven contingency factors, of which eight are classified into external and organisational characteristics and three are innovation related. The traditional contingency factors have been included in this innovation company context as this paper represents an academic inquiry discussing which contingency factors might be relevant and to which extent they influence MCSs in the companies studied.

Over the years numerous other potential contingency factors have been investigated; for example, factors concerning the superior-subordinate relationship such as leadership style (Hopwood 1974; Merchant 1985a, 1990), managerial roles (Macintosh and Williams 1992), trust (Ross 1995) and information asymmetry between superiors and their subordinates (Dunk 1992). Furthermore, various aspects of personality characteristics were used as contingency factors in MCS research: locus of control (Govindarajan 1988), authoritarianism and collectivism (Harrison 1993). Also specific firm characteristics such as diversification in a company's structure or product line (Hoskisson et al. 1990) have been investigated. In his study on the emergence of MCS in small growing firms, Davila (2005) examined the replacement of the founder with a professional manager as a contingent factor.

Some of the contingency factors mentioned have provided insights in the design of MCSs generally. However it is the aim of this study to build a model of the centrally important contingency factors that influence MCS design specifically in innovation companies. Therefore a detailed view on the relationship between superior and their subordinates and personality characteristics of managers is not included. Firm structure is included via the level of decentralization and the contingency factor 'ownership dispersion' which includes family owners who are expected to be close to the companies' management. 
The framework explores the association between eleven identified contingency variables and the application of the MCS types; hence a 'selection approach' within the framework of contingency theory has been chosen (Drazin and Van De Ven 1985). This approach, unlike the 'interaction approach' and 'systems approach' (Drazin and Van De Ven 1985), investigates the context-MCS relationships without linking these associations to performance (Merchant 1985b). It relies on the assumption that only the fittest organisations survive (Chenhall and Langfield-Smith 1998; Chenhall 2003). The selection approach has been widely adopted in MCS research (e.g. Carr and Tomkins 1996; Fisher 1996; Chow et al. 1999; Guilding and McManus 2002; Davila 2005; Gerdin 2005; O’Connor et al. 2006).

As argued by Fisher $(1995,1998)$ company performance is not contingency theory's only outcome variable $^{7}$ and, since it is affected by many variables other than MCSs, the effect of MCSs is expected to be quite low (Otley 1980). Donaldson (2001) renamed the 'selection approach' of fit 'managerial choice', as the adoption of organisational dimensions to contextual variables is based on managerial decisions. In addition, it is widely argued that managers would not install MCS instruments that are not expected to enhance performance (Chenhall 2003). The 'selection approach' is therefore the most appropriate contingency approach for the purpose of modelling why particular MCSs are applied by innovation companies. Although it is expected that MCSs are used due to 'managerial choice', our model also includes contingency factors which can be directly traced to an external force such as customer power, venture capital financing or public funding. However, it is argued that, ultimately, the management decides whether or not to comply with such external pressure by intensifying certain MCS categories. Therefore the 'selection approach' is still argued to be applicable.

Numerous schemes for classifications of contingency variables have been proposed and used in MCS research (e.g. Fisher 1995; Merchant 1997; Abdel-Kader and Luther 2008; Drury 2008). However, as the contingency factors studied vary with the respective research question, these lists cannot be seen as exhaustive. This study follows the categorization of Abdel-Kader and Luther (2008), but modifies the third category adjusting it to the innovation companies addressed in this framework. In their examination of firm characteristics on management accounting practices in the UK food and drink industry, Abdel-Kader and Luther (2008) distinguished the following categories: external, organisational, and processing

\footnotetext{
For instance, organisational outcome variables are effectiveness, efficiency, job related tension and satisfaction (Fisher 1998).
} 
characteristics. As the processing characteristics ${ }^{8}$ are not a focus for innovation companies, this will be replaced by a category referred to as innovation related characteristics. The following sub-sections elaborate on the eleven contingency factors that are included in the framework.

\subsubsection{Contingency factors: External characteristics}

Two variables of an innovation company's external environment are expected to be potentially relevant: environmental uncertainty and customer power. Environmental uncertainty is acknowledged to be one of the key contingency factors in MCS research (Chapman 1997; Chenhall 2003). For example, as Chong and Chong (1997) revealed, more sophisticated management accounting systems (MASs) ${ }^{9}$ are able to support reduction of uncertainty and improvements of decision-making. Research \& development (R\&D), as a functional area facing a high environmental uncertainty, benefits from the application of results, action and personnel control for the generation of radical innovations (Cardinal 2001). In order to operationalize environmental uncertainty, the measure of Govindarajan (1984) has been selected; containing one question for the respondent's perceived environmental uncertainty concerning eight different environmental influences. The measure is chosen due to its respondent-friendly structure and compactness compared to other measures such as in Miles and Snow (1978, p. 200) and Khandwalla (1972, 1977).

Although the influence of a number of large customers on an enterprise's MCS has so far not been studied intensively (Abdel-Kader and Luther 2008), the impact of customer power on control systems and its relevance for innovation companies was revealed during the preliminary qualitative study. In line with O’Connor et al. (2011), customer power is assumed to be prevalent if few customers make up a large share of a company's total sales. The managers of three innovation companies explained that having a few large customers, requiring for instance a specific quality management certificate (ISO 9000), influences the design of results and action control. This supports Kelly and Gosman (2000)'s finding that large customers may cause changes in business practices such as inventory management, pricing, promotion and product development of their smaller suppliers.

\footnotetext{
$8 \quad$ E.g. system complexity, product perishability, advanced management technology

9 Management accounting systems are part of the overall MCS framework, mainly in the category of results control.
} 


\subsubsection{Contingency factors: Organisational characteristics}

Six different contingency factors in the category of organisational characteristics are included in the framework: business strategy, technological complexity, decentralisation, ownership, firm size and organisational maturity.

Business strategy is widely addressed in MCS research (Otley 1999; Chenhall 2003) as strategic decisions “take on meaning only as they are implemented through the organization's structure and processes” (Miles and Snow 1978, p. 7) and therefore influence the design of the organisation's MCSs (Langfield-Smith 1997; Chenhall 2003). There are three main typology frameworks of business strategy which have had a substantial impact on MCSs contingency-based research: strategic pattern of Miles and Snow (1978), strategic position of Porter (1980) and strategic mission of Gupta and Govindarajan (1984). Despite the differences in their inward/outward focus, Segev (1989) showed that the typologies of Miles and Snow (1978) and Porter (1980) are consistent and argues that "it is no longer necessary for researchers to enrich their view of a strategic situation by the separate application of each typology” (Segev 1989, p. 500). This framework will adopt Porter’s (1980) differentiator and cost leadership categories, as the typology particularly concerns the different types of innovations and the two ends of the entrepreneurial continuum have been widely adopted in the MCS literature (e.g. Govindarajan 1988; Bruggeman and Van der Stede 1993; Auzair and Langfield-Smith 2005; Abdel-Kader and Luther 2008). Differentiators aim to offer unique products with an emphasis on marketing and research and hence on product innovation; whereas cost leaders offer standardised products at low prices while reducing production costs, for example with process innovations (Porter 1980). In order to account for dynamic changes in managerial decision making, this framework recognises Gilbert and Strebel (1987)'s outpacing strategies, which assume that a company may strive for both differentiation and cost leadership. The survey instrument of Chenhall and Langfield-Smith (1998) accounts for the fact that companies may pursue both of these strategic types in varying degrees, and is therefore the basis for the business strategy measure in this framework.

Technological complexity is of specific relevance for innovation companies and is another key contingency factor in MCS research (Chenhall 2003). Chenhall (2003) condensed different approaches of technology (Woodward 1965; Perrow 1967; Thompson 1967) and summarizes their potential impact on MCSs. For organisations with tailor-made, nonstandard, differentiated products that operate with complex unit technologies, the use of traditional, mechanistic MCSs with a focus on financial control is not appropriate. In contrast, 
organisations producing undifferentiated standard products using a well-known mass or process production technology are recommended to adopt standardised administrative ${ }^{10}$ controls with a focus on traditional, financial controls (Chenhall 2003). This framework includes technological complexity measured in terms of novelty of technology and technical difficulty of the production processes based on a measure of Carbonell and Rodriguez (2006).

Organisational structure is a third important contingency factor for MCS research, as an enterprise's structure affects information flows, individual motivation and control systems (Chenhall 2003). Operationalisation of organisational structure includes variables such as complexity, formalisation, administrative intensity, and decentralisation (Govindarajan 1988). Of these four variables, decentralisation is chosen as the proxy for structure in this framework, because complexity is partially reflected by environmental uncertainty and technological complexity. Formalization and administrative intensity are also characteristics of MCSs and are therefore unsuitable for operationalising structure, since otherwise the same phenomena would be used for both the contingency factor and the direct/indirect types of control. The extent of decentralisation is operationalised using the measure of Gordon and Narayanan (1984) due to its broad scope and brevity compared to other measures (e.g. Govindarajan 1988). According to Chenhall and Morris (1986, p. 17) decentralisation concerns the "degree of autonomy delegated to managers". In particular for innovation enterprises, decentralisation is required in order to provide flexible communication and decentralised decision-making, which are components of Burns and Stalker's (1961) organic style of management. Damanpour (1991) and Wan et al. (2005) both confirmed that decentralisation is positively related to organisational innovation. Furthermore, a study in 80 Spanish SMEs showed that decentralisation is a significant influential factor for innovation outcomes (Martínez-Román et al. 2011). Hence, although decentralisation may be related to firm size (Pugh et al. 1969), it is included as a separate contingency factor, in order to account for different decentralisation tendencies expected for innovation companies independently from their firm size.

Studies have shown that ownership structure plays a vital role in the design of an enterprise’s MCS (Kamin and Ronen 1978; Jones 1992; Whitley 1999; Sandino 2007). Ownership may affect how proactively MCSs are designed by managers and the extent to which they are receptive to changes (Ferreira and Otley 2010). Ownership structure is reflected in this framework by using the concept of 'ownership dispersion', i.e. the extent to

10 In this context, administrative controls refer mainly to results control but also action control (see Chenhall 2003). 
which company shares are diffused among different owners. Family-owned companies have the lowest degree of ownership dispersion; those with a few large corporate owners represent partial ownership dispersion. The strongest ownership dispersion is where firms are owned by a large number of minority owners, particularly if the shares are listed. Since there is significant variation in ownership structure of innovation companies, it is adopted as a contingency variable.

Firm size, measured by numbers of employees ${ }^{11}$, is seen as a critical dimension for organisational structure and control activities, as it limits the possibility of managers to personally monitor their subordinates (Child 1973b). As the size of a company increases the amount of information to be processed by management rises: an arithmetical increase in organisational members leads to an exponential increase in communication networks (Kimberly 1976). Therefore, with increasing size informal controls become less suitable and control has to become more formalised (Davila 2005). As innovation activities are undertaken by companies of all sizes (OECD 2005) and firm size is seen as an influential contingency factor it is included in this framework.

Organisational maturity is selected as the final contingency variable of this category. Life cycle theory argues that organisational life can be divided into different stages, with each of these stages being characterized by a specific environmental and organisational context; accordingly, different organisational structures and strategies, and levels of innovation are apparent (Miller and Friesen 1983). The stage of a company’s life cycle only gained interest as a contingency variable in MCS research quite recently. It was shown that enterprises display a stronger emphasis on bureaucratic MCSs at the mature stage than in earlier growth stages of their life cycle (Moores and Yuen 2001; Auzair and Langfield-Smith 2005; Granlund and Taipaleenmäki 2005). Organisational life cycle stage is different from firm size. As shown by the study of Moores and Yuen (2001) firm size does not increase gradually through the companies' life cycle stages. However, potential correlation would need to be tested when empirically assessing the framework. As the relevance of the organisational life cycle has been confirmed for high-tech firms (Granlund and Taipaleenmäki 2005) and also for SMEs (Hutzschenreuter 2009) the impact of organisational maturity on MCS design is assessed in this study. Due to its focus on technology driven companies the measure of Kazanjian (1988) could be applied. Companies in the start-up, commercialisation and growth

11 The OECD recommends to measure firm size on the basis of number of employees in the Oslo manual (2005, p. 72) and the Frascati manual (2002, p. 62) in order to ensure comparability. 
stage are considered as immature companies, whereas mature companies are in the stability stage of the life cycle.

\subsubsection{Contingency factors: Innovation related characteristics}

Three contingency factors which are particularly relevant in an innovation context, innovation capability, venture capital financing and public funding, are considered in a separate category.

The common characteristic of the companies examined in this paper is their striving for innovations. One of the main factors in this context is an enterprise's innovation capability, which is understood in this study as "the ability of the actors to generate, diffuse, and utilize innovations that have economic value” (Yam et al. 2011, p. 392). Although all of the enterprises in this research are innovative in nature, their degree of innovation capability will differ. $^{12}$ The term 'innovation capability' needs to be distinguished from 'innovativeness'. The former concerns the "implementation or adoption of innovation" whereas 'innovativeness' describes the "initiation of and receptivity to innovation” (Hurley and Hult 1998, p. 45). The measure used by Nassimbeni (2001) is selected as it is applicable to a wide range of innovation companies and contains a measure of inter-organisational relationships arising from increasing networking tendencies between innovation companies. In addition, it does not require respondents to provide commercially sensitive figures and is therefore respondent-friendly. The original measure of Nassimbeni (2001) identifies the following components of innovation capability: ability to generate product and process innovations, amount of investment in innovation, inter-organisational relationships. ${ }^{13}$

In order to develop innovation capability, enterprises need to adjust their organisational structure, strategy (Nonaka and Takeuchi 1995), and market, learning and entrepreneurial orientation (Hult et al. 2004). Several studies on MCSs have acknowledged the role that the specific characteristics of innovative enterprises play regarding the implementation and design of MCSs. For instance, the importance of control through the expenditure budget ${ }^{14}$ rises with the size of $R \& D$ work groups, increasing external $R \& D$ funding and increasing budget size (Rockness and Shields 1988). In his study of MCSs in new product development

12 For a review of the concept of innovative capability see Martínez-Román et al. (2011).

13 The fourth component of this original measure, human resource management (HRM), is not used in this framework in order to avoid any collinearity problems with the construct of personnel control.

14 Rockness and Shields (1988, p. 577) measured “control through the expenditure budget” as "perceived importance of the expenditure budget for management control of R\&D”. 
settings, Davila (2000) reveals that project uncertainty and product strategy are crucial to MCS design. Cost and design information show a positive effect on product development performance, and time information a negative effect. In his investigation of MCSs in knowledge-intensive companies, Ditillo (2004) found that depending on the type of knowledge complexity prevalent in a firm, different control types have to be applied: computational complexity requires action control, technical complexity tends to be regulated through results control and cognitional complexity requires competencies, values and beliefs. Control in these companies is seen to fulfil two roles: coordination of activities and integration of knowledge. In early-stage entrepreneurial companies Davila et al. (2009) identified the following reasons-for-adoption of new product development MCSs: legitimization of the company, contracts with other organisations, a proactive management background and proactive need to focus, as a reaction to chaos or learning. Our framework acknowledges that enterprises which strive for innovation need specific MCSs which fit their specific characteristics. Therefore innovation capability is included as a contingency factor.

More recently, type of financing has been identified as a factor potentially influencing the implementation and design of MCSs (e.g. Sweeting 1991; Mitchell et al. 1997; Davila 2005; Davila and Foster 2005, 2007; Sandino 2007; Silvola 2008). The crucially important role of venture capital (VC) as a source of financing in particular for innovation and high-technology companies is well acknowledged (Rosenstein et al. 1993). Furthermore, Granlund and Taipaleenmäki (2005) confirm that the presence of VC funding leads to more sophisticated MCSs. Venture capital in an innovation company is understood in this framework as 'short/medium term equity funding by an investment company'. A measure could for example build on Howorth and Westhead (2003) by asking respondents for the extent of use of venture capital as a source of financing.

The third contingency factor in this innovation related category is public funding which was identified during this project's preliminary qualitative study. Managers of innovation companies argued that controls have been adopted as a response to the application procedures for public funding. In order to protect public funds, strict requirements have to be fulfilled before public funding can be received; it differs from private funding, as for receiving public funding, the required controls need to be installed ahead, whereas for private funding controls are often implemented during the financing process. In addition, private investees are rather interested in long-term controls, for example venture capitalists require financial budgets (Bruining et al. 2004), or operating and cash budgets (Davila and Foster 2005) to be installed on a regular basis whereas for public, generally non-equity, funding 'only' cost projections or 
process steps of the respective project have to be provided. It became clear that public funding is an important issue in $R \& D$ projects which are frequently recipients of considerable amounts of such funds. In order to apply for governmental funding, several requirements generally have to be met; depending on the funding source, the application needs to include a projection of R\&D process steps, milestones and detailed cost figures, which are instruments of the categories action and results control. The authors are not aware of public funding having previously been applied as a contingency factor in MCS research. However as the relevance of this source of financing as an influential factor on control has been stressed by managers during the preliminary qualitative study, it is included. Public funding could, like venture capital, be measured by means of a single question about the extent of use of public funding as a source of financing.

\section{Development of hypotheses}

In this section, relevant findings of the MCS literature are briefly reviewed in order to derive the hypotheses relating to eleven contingency factors and their predicted association with the four MCS categories. In the narrative that follows, an association of a contingency factor with MCSs is interpreted as a relationship which would be empirically manifested by a change in the intensity of use of the respective MCS category.

\subsection{External characteristics and the four categories of MCSs}

\subsubsection{Environmental uncertainty and categories of MCSs}

Results control serves as an ex-post control mechanism. Originally Thompson (1967) postulated that performance standards cannot be set if there is high environmental uncertainty, and that reliance on results control was inappropriate for settings of high uncertainty and information delivered by accounting measures was seen to be incomplete (Hirst 1981).

However, later studies (Gordon and Narayanan 1984; Chenhall and Morris 1986) found positive associations between environmental uncertainty and use of supplementary external, non-financial and prospective accounting information. Specifically, Chenhall (2003) maintains that results control can actually support decision making in uncertain situations. Similarly, Kärreman et al. (2002) acknowledged that MASs support uncertainty reduction and results control applied in an $R \& D$ setting was found by Cardinal (2001) to enhance both incremental and radical, innovations.

Thus we hypothesize: 
H1a: The extent of results control is positively associated with the degree of environmental uncertainty an innovation company faces.

In contrast, the use of action control is viewed to be negatively associated with environmental uncertainty. The application of action control requires that managers must possess knowledge about means-end relationships (Ouchi 1977). But in uncertain situations, a procedure cannot be prescribed and administrative and technical barriers may hamper the production process in unexpected situations. Additionally, of particular relevance for innovation companies, several authors warn that too intensive action control may result in routine actions and a resistance to change (Merchant 1985b; Jaworski 1988; Cardinal 2001; Sarin and Mahajan 2001; Bonner 2005). There is consensus that concentration on action control may lead to an overemphasis of internal processes and the inability of employees to deal with uncertainty (Merchant 1985b).

H1b: The extent of action control is negatively associated with the degree of environmental uncertainty an innovation company faces.

Abernethy and Brownell (1997) confirmed the importance of personnel control if there is high uncertainty. If employees are selected and trained well, they are better able to assess how different aspects of external uncertainty will affect internal processes (Chapman 1997). Hence in settings with high uncertainty the company will seek to enable its employees to cope with uncertain situations through personnel control. Accordingly, it is proposed:

H1c: The extent of personnel control is positively associated with the degree of environmental uncertainty an innovation company faces.

According to Speklé (2001), when confronted with high uncertainty, enterprises will strive to establish an environment of commitment and congruency in order to achieve organisational goals. In particular, in the highly uncertain environment in which knowledge-intensive and high-tech companies operate, Alvesson (1993a) finds that cultural control is important. This opinion was also expressed by Ouchi $(1979,1980)$, one of the first authors discussing the existence of cultural control which he labelled 'clan control'. Cultural control seeks to create overall commitment through shared values and social norms and is therefore well suited.

H1d: The active promotion of cultural control is positively associated with the degree of environmental uncertainty an innovation company faces. 


\subsubsection{Customer power and categories of MCSs}

Since powerful customers decrease a company's ability to charge high prices, it is argued that cost pressure is much stronger for companies that are confronted with high buyer power (Scherer and Ross 1990). This was also reflected by the study of O’Connor et al. (2011) who showed that large international customers exert pressure on their suppliers’ profit margins. Furthermore, Fuentes-Fuentes et al. (2007) revealed that companies that were confronted with high buyer power stressed quality management techniques that pursue a cost reduction strategy. As results control is an important tool for strategies of cost reduction (Miles and Snow 1978; Porter 1980), it is hypothesised:

H2a: The extent of results control is positively associated with the degree of customer power faced by an innovation company.

A positive impact of customer power ${ }^{15}$ on action control is expected. Strong business dependency can lead to pressure on a company to copy the patterns of behaviour of the stronger business partner (Guler et al. 2002). In particular it has been shown that powerful customers are a main reason for obtaining quality certifications (e.g. Rayner and Porter 1991; Vloeberghs and Bellens 1996; Brown et al. 1998). The adoption of quality systems in order to obtain certification is accompanied by increased formalisation and documentation to provide transparency of the characteristics of all organisational activities (Santos and Escanciano 2002). For example, the following six stages need to be undertaken when implementing a quality management system: planning of the implementation, documentation planning, definition of all organisational processes and quality practices, verification and validation of the quality management system, deployment and continuous improvement (Nanda 2005). Thus the implementation of quality management systems in order to obtain the ISO 9001 certificates requires compilation of all organisational processes in a manual, in which each process is described and competencies are defined, i.e. action control. Due to the strong influence of large customers on procedures performed by their suppliers it is hypothesised:

$\mathrm{H} 2 \mathrm{~b}$ : The extent of action control is positively associated with the degree of customer power faced by an innovation company.

Obtaining quality certificates due to high customer power leads to employee participation and an enhanced learning environment in the enterprise (Santos and Escanciano 2002).

15 As explained in Section 2.2.1, high customer power is expected to be prevalent if few customers make up a large share of a company’s total sales based on a measure of O’Connor et al. (2011). 
Additionally, through the diffusion of patterns of behaviour to the dependent organisation, technical and scientific knowledge of the customer becomes available to the supplier (Guler et al. 2002). In the preliminary qualitative study for this framework, one of the managers reported that, in some industries, the supplier is required by its larger customers to send employees to workshops regularly. Therefore a positive impact of high customer power on personnel control is predicted:

H2c: The extent of personnel control is positively associated with the degree of customer power faced by an innovation company.

Although there are few studies of the impact of customer power on the application of cultural control, a positive association is expected. Gupta and Govindarajan (2000) described the tendency towards socialization in supply chains, defined as "the level of interaction between, and communication of, various actors within and between organizations, which leads to the building of personal familiarity, improved communication and problem solving” (Cousins and Menguc 2006, p. 607). Through socialization within supply chains, enterprises learn from their business partners social values e.g. their "rules of thumb, special language, ideology that helps to edit a member's everyday experience, standard or relevance of work, prejudices, and models for social etiquette” (Cousins et al. 2006, p. 853). Hence it is hypothesised that:

H2d: The active promotion of cultural control is positively associated with the degree of customer power faced by an innovation company.

\subsection{Organisational characteristics and the four categories of MCSs}

In the following sub-sections, hypotheses concerning six organisational contingency factors and their impact on the MCS categories are derived.

\subsubsection{Business strategy and categories of MCSs}

Although the use of some results controls has been shown to benefit companies following a differentiation strategy (Simons 1987; Collins et al. 1997), these findings stand in contrast to arguments that a differentiation strategy, being achieved through creativity and innovation, requires less formal types of control (Miles and Snow 1978; Van der Stede 2000). It was shown that financial controls were less intensively monitored in differentiator-type companies (Porter 1980), and differentiators with less intensive use of budgetary controls are more effective (Govindarajan 1988; Govindarajan and Fisher 1990). Cost leaders, pursuing the 
opposite business strategy, have been found to use cost controls in order to monitor costs and achieve operating and cost objectives. They display an emphasis on controls that enhance efficiency and problem solving (Miles et al. 1978; Dent 1990; Langfield-Smith 1997), leading to the following hypothesis:

H3a: Innovation companies following a differentiation strategy will place less emphasis on results control than companies following a cost leadership strategy.

Too intensive action control may lead to an overemphasised focus on the realisation of prescribed actions instead of experimentation and a flexible response to customer satisfaction (Bonner 2005) and is therefore not beneficial for differentiators. However, companies pursuing a cost leadership strategy require the creation of standard procedures (Miles and Snow 1978), a continuous improvement of their existing processes (Hamel and Prahalad 1994) and reduction of non-value added activities (Hayes et al. 1988, cited in Chenhall \& Langfield-Smith (1998)) and may therefore rely strongly on action control. Thus,

H3b: Innovation companies following a differentiation strategy will place less emphasis on action control than companies following a cost leadership strategy.

Arthur (1992) reported that a differentiation strategy is linked to employee training and skills. Likewise, Peck (1994) revealed a positive impact of a differentiator-type strategy on the application of personnel control. Although personnel control is also important for cost leadership-type companies in order to develop highly specialised jobs (Miles et al. 1978) and personnel with process engineering skills and experience in the realisation of economies of scale (Govindarajan and Fisher 1990), it seems to be even more relevant for differentiatortype companies. Thus,

H3c: Innovation companies following a differentiation strategy will place higher emphasis on personnel control than companies following a cost leadership strategy.

Interpersonal control, consisting of the personnel and cultural control categories, has been found appropriate for differentiators, as employees in these companies should be free of inflexible limits to creativity and flexibility (Auzair and Langfield-Smith 2005). Also, Peck (1994) reported that differentiators are associated with a work culture based on cooperation, trust and mutually supportive behaviour. Osterman (1994) showed that companies following a differentiation strategy tend to apply more flexible work practices such as work teams and job rotation which foster cultural control. In summary, as the implementation of shared norms and values seems to be more important for a differentiation strategy it is proposed that, 
H3d: Innovation companies following a differentiation strategy will place higher emphasis on the active promotion of cultural control than companies following a cost leadership strategy.

\subsubsection{Technological complexity and categories of MCSs}

Technological complexity is understood in this study in terms of novelty of technology and technical difficulty of the production processes based on a measure of Carbonell and Rodriguez (2006). The dimension 'technical difficulty of the production processes' of this concept of technological complexity captures Perrow (1970)'s notion of task uncertainty defined by the two dimensions task analysability and number of exceptions. In highly complex settings, it becomes more difficult to express the outcome of transformation processes in numbers; relying on accounting figures, a main component of results control, is inappropriate (Chapman 1997). This was corroborated by Abernethy and Brownell (1997) showing that the application of accounting controls in settings of high task uncertainty leads to reduced R\&D performance. Thus, it is hypothesised:

H4a: The extent of results control is negatively associated with the degree of technological complexity prevalent in an innovation company.

Van de Ven et al. (1976) showed that with increasing task uncertainty an impersonal mode of coordination by rules, procedures, plans and schedules decreases, in favour of more personal and group-based modes of coordination. This is in line with arguments of Reeves and Woodward (1970) that in situations of high technological complexity, management is not able to prescribe all activities and processes to be undertaken, hence making action control unsuitable. Similarly, Snell (1992) confirmed the negative impact of workflow integration on the use of action control. Summing up these arguments, it is expected that

H4b: The extent of action control is negatively associated with the degree of technological complexity prevalent in an innovation company.

Snell and Dean (1992) stressed the role of a skilled labour force by showing that the use of advanced manufacturing techniques is positively related to the intensity of personnel control. In settings with low task analysability and a high number of exceptions, the application of personnel control was shown to be positively related to R\&D performance (Abernethy and Brownell 1997). Thus, we share the view that more complex technologies require a highly skilled labour force, so management will stress careful employee selection and training and development. It is therefore expected that, 
H4c: The extent of personnel control is positively associated with the degree of technological complexity prevalent in an innovation company.

Wilkins and Ouchi (1983) suggest that in situations of high ambiguity and difficulty, as for high technological complexity, direct types of control need to be replaced by cultural control. Technological complexity requires a high degree of functional speciality because tasks are less repetitive and routine, demanding sophisticated problem-solving procedures. Hence employees need to be fully committed to their specific tasks, thus reducing competition within the firm because each organisational member has a specialised task. This 'moral commitment', as coined by Baliga and Jaeger (1984), fosters cultural control, which management will aim to increase. Thus,

H4d: The active promotion of cultural control is positively associated with the degree of technological complexity prevalent in an innovation company.

\subsubsection{Decentralisation and categories of MCSs}

Results and action controls are used to a greater extent in decentralised firms (e.g. Bruns and Waterhouse 1975; Merchant 1981, 1984). More specifically, it was shown that in decentralised companies, managers will seek information which is more aggregated and integrated (Chenhall and Morris 1986), will increase the use of divisional performance measures (Abernethy et al. 2004) and will use more sophisticated MA practices (Abdel-Kader and Luther 2008). Overall, if there is a high extent of decentralisation, the MCS literature reveals that there will be an increased need for results control in order to ensure that organisational goals are achieved. It is therefore expected:

H5a: In innovation companies the extent of results control is positively associated with the degree of decentralisation.

The use of action control is considered unsuitable in decentralised companies as, once decision-making authority has been delegated, actions cannot be prescribed since lower level managers decide which actions to take and how these have to be realised (Williams and van Triest 2009). In addition, close supervision, also part of action control, is less possible in decentralised structures. Snell (1992) drawing on the organisational models of Thompson (1967) and Ouchi $(1977,1978)$ therefore concludes that while results control is useful for decentralised companies, action control is not. Therefore in decentralised companies, action control will be replaced by results control and the indirect control categories. 
H5b: In innovation companies the extent of action control is negatively associated with the degree of decentralisation.

Decentralisation has been shown to lead to higher levels of perceived agent authority as activities are controlled by lower management levels (Child 1973a). Management must ensure that subordinates are able to take decisions that are in line with the organisational goals and to carry out these decisions effectively. Also Perdomo-Ortiz (2006) argues that personnel control is key to empowerment and delegation of decision making authority. Hence self-control which is the essence of personnel control, needs to be enabled by increased focus on the selection of new employees and their subsequent training and development. Therefore it is expected that,

H5c: In innovation companies the extent of personnel control is positively associated with the degree of decentralisation.

Lawrence and Lorsch (1967) maintained that decentralisation on the one hand goes with a higher diversity of management techniques, norms and values; but on the other hand there is a greater need for coordination and integration. Weick (1987, p. 124) argues that a shared culture is needed in decentralised organisations because it "adds in latitude for interpretation, improvisation, and unique action”. These behaviours are especially required in the innovation companies of this framework. This would foster the argument that cultural control is an important category of control in decentralised companies. It is therefore hypothesised:

H5d: In innovation companies the active promotion of cultural control is positively associated with the degree of decentralisation.

\subsubsection{Ownership and categories of MCSs}

Concentration of ownership has been found to be positively associated with centralisation, but negatively associated with formalisation and to a weaker extent with standardisation (Child 1973a). Davila (2005) maintains that the founder, viewed as close ownership in this study, may potentially be replaced by a new CEO if the company requires professional management when it starts growing. In his study the replacement of the founder by a new CEO was linked to the adoption of results control. Reid and Adams (2001) confirmed that a significantly higher proportion of non-family firms used appraisal systems for managers than family firms. Also, after a company has gone public on a stock exchange, groups of stakeholders demand that it implements sophisticated controls and installs professional management (Granlund and Taipaleenmäki 2005). In summary, it seems that dispersed ownership is associated with 
greater reliance on results control, because there is a stronger external pressure to implement results control. Incentive contracts based on results are frequently used to align the interests of managers with those of owners. Furthermore, dispersed minority shareholders need to use results control to keep track on the business from a distance. Therefore it is expected that,

H6a: The extent of results control in innovation companies is positively associated with the dispersion of share ownership.

Originally Child (1973a) held that a concentration of ownership was related to centralisation, requiring more standardised rules and procedures (Whitley 1999). In addition, as Whitley (1999) argued based on theoretical considerations, owners of large blocks of shares are more locked into their company, making it more difficult to change their major decisions and hence they might insist on running a formal system of rules. However, more recent empirical evidence shows that dispersed ownership tends to positively influence the adoption of action control. For instance, evidence was found that CEO replacement had a significant positive effect on action control, in particular for small firms (Davila 2005). This was interpreted as an early replacement of the founder, by an experienced CEO, being related to the founder's inability to install action control (Davila 2005). Johannisson and Huse (2000) argue that owners of traditional family businesses, representing close ownership, usually stay close to the specific operations of their company. It can therefore be expected that familyowners do not install formal rules and procedures because they know their business and its operations and are able to monitor these without a high extent of formalisation and standardisation. Based on the empirical evidence of previous studies it is expected that,

$H 6 b$ : The extent of action control in innovation companies is positively associated with the dispersion of share ownership.

A positive impact of ownership dispersion on personnel control is expected as founders usually control their company and established staff with their vision but often fail to transfer their vision to new employees (Davila 2005). The replacement of the founder by a new CEO was shown to have a positive effect on the adoption of personnel control (Davila 2005). O’Connor (1995) reports that local family-owned companies were less focussed on training and development of managers. Therefore in this study on innovation companies it is expected that,

H6c: The extent of personnel control in innovation companies is positively associated with the dispersion of share ownership. 
Although the importance of social control exerted by the entrepreneur was stressed in a case study of Collier (2005), it is expected that the instruments of cultural control are more intensively applied in companies with a separation between ownership and control. For example, Grugulis et al. (2000) report from a case study that the management started to institutionalize events, such as weekend outings, sports competitions or fundraising events, that had previously been executed by the owner-manager in a personal manner; in addition a culture statement was developed by the 'cultural manager' of this firm. Reid and Adams (2001) confirmed that a significantly higher number of non-family firms adopted a mission statement than family firms. Thus,

H6d: The active promotion of cultural control in innovation companies is positively associated with the dispersion of share ownership.

\subsubsection{Firm size and categories of MCSs}

In growing organisations with an increasing number of hierarchical levels, management will experience an increasing loss of control (Williamson 1975). Also in the MCS literature growing firm size was found to cause communication and control problems (Merchant 1981, 1984). Child (1973b, a) found organisational size to be positively related to standardisation, formalisation and specialisation. As shown by Burns and Waterhouse (1975) and Merchant (1981), with growing firm size management tends to apply more formal and highly developed budgeting systems and more intensive management involvement in budgeting. As firms grow they are also more likely to implement the Balanced Scorecard (Hoque and James 2000), which is a comprehensive type of results control. In addition, Holthausen et al. (1995) revealed a positive impact of firm size on proportion of managers' compensation based on long-term results. Hence it is expected that,

H7a: In innovation companies, the extent of results control is positively associated with firm size.

With growing firm size, impersonal action control becomes more formalised using procedure guides, rules and manuals that take over the role of direct supervision (Snell 1992). Davila (2005) corroborated that firm size was positively associated with the extent of formalisation of action control. This finding was explained by the need for codification and documentation of organisational knowledge into routine actions which require less management attention. In summary, it is expected that management needs to rely on formal rules and procedures if firm size increases. Hence, 
H7b: In innovation companies, the extent of action control is positively associated with firm size.

Snell (1992) showed that the extent of personnel control increases with firm size. An explanation was that large firms tend to spend more money on human resource management. As Ouchi (1979) argued, selection and training programmes are used in order to socialise organisational members in order to achieve organisational goals through self-control. Also Davila (2005) confirmed that firm size is positively related to the adoption of personnel control. It is therefore expected that,

H7c: In innovation companies, the extent of personnel control is positively associated with firm size.

Merchant and Van der Stede (2012) report that in successful small companies, each task is well understood and employees spontaneously form a group and are highly motivated; therefore cultural control is relatively inexpensive. If a company grows, it may be difficult for employees with differing cultural backgrounds to share the values of the rest of the organisation. Therefore the deployment of active cultural controls has to be increased in order to foster the development of a corporate belief or value system which is the basis of mutual control among organisational members. In particular the mission statement is a useful tool to deliver organisational values to a growing number of employees (Analoui 2001). Hence it is expected that with growing firm size managers will apply more controls in order to foster shared values and norms among subordinates. Although it could be argued that many innovation companies are relatively small and therefore more exposed to environmental uncertainty, there is nevertheless, following Merchant and Van der Stede (2012) and Analoui (2001), less requirement for managers to actively promote cultural controls, i.e. by institutionalising instruments such as mission statements, firm events, dress codes or firm specific vocabulary. In view of this the following is hypothesised:

H7d: In innovation companies, the active promotion of cultural control is positively associated with firm size.

\subsubsection{Organisational maturity and categories of MCSs}

As companies become more mature, moving from start-up through commercialisation and growth, the complexity of decision-making and information processing rises (e.g. Miller and Friesen 1983; Gul 1991; Gupta and Chin 1991; Simons 1995). With progression through each stage, MA practices need to deliver more information with a differing focus in order to enable 
managerial decision-making (Moores and Yuen 2001). Several studies have shown that the extent of results and action control increases from early to mature stages of the life cycle (Moores and Yuen 2001; Auzair and Langfield-Smith 2005; Granlund and Taipaleenmäki 2005) which is also in line with the pioneering models of Miller and Friesen $(1983,1984)$ and Kazanjian (1988). Therefore, for both types of direct control, a positive impact of organisational maturity is expected:

H8a: The extent of results control is expected to be higher in mature innovation companies than in immature innovation companies.

H8b: The extent of action control is expected to be higher in mature innovation companies than in immature innovation companies.

Companies will have to hire employees in order to be able to carry out all business activities as they progress through the life cycle stages (Miller and Friesen 1983). Mature companies, as Schuler (1989) maintains, already have their own internal labour market and have established training and development programmes. Jobs tend to be more specialised providing a further challenge for employee selection and staffing. With respect to innovation companies, Chow and Gong (2010) confirm that knowledge-based and commitment-based HR policies play the most important role in the growth stage of technology-intensive companies. As HR policies take time to be developed and implemented, it is expected that in mature companies personnel control will be more sophisticated.

H8c: The extent of personnel control is expected to be higher in mature innovation companies than in immature innovation companies.

Cultural control refers to group control exerted through an internalized system of shared beliefs and values (Merchant and Van der Stede 2012). A major prerequisite for this internalization is long-term employment, i.e. employees should be employed by one company for a long period to be very loyal to it and behave in a desired manner (Baliga and Jaeger 1984). Although there are arguments that immature firms have a more innovation- and creativity-seeking culture (Bahrami and Evans 2000), this could also mean that managers of mature companies need to implement specific tools such as a mission, group based rewards, and organisational events in order to maintain this cultural intensity. This argument, in line with the finding that culture needs a long-term horizon in order to be internalized (Baliga and Jaeger 1984) and that the adoption of cultural control takes a longer period of time (Wilkinson and Oliver 1992), leads to the hypotheses that 
H8d: The active promotion of cultural control is expected to be higher in mature innovation companies than in immature innovation companies.

\subsection{Innovation related characteristics and the four categories of MCSs}

We turn now from contingency factors affecting companies generally to those characteristics particularly associated with their striving for innovation, and consider the relationship between those characteristics and MCSs.

\subsubsection{Innovation capability and categories of MCSs}

Highly innovative firms experience difficulties balancing the need for control of their business on the one hand, against the requirement for flexibility in order to be able to generate innovations on the other hand (Lukka and Granlund 2003). Innovation capability is measured in this model using Nassimbeni's (2001) three components: ability to innovate or develop product and process innovations, investments in innovation, and inter-organisational relationships. With regards to results control, it was argued that a strong focus on this at the divisional level, can lead management to lose sight of strategic investments, especially in R\&D and therefore long-term growth and sustainability (Hill and Hoskisson 1987). Granlund and Taipaleenmäki (2005) report that often CEOs of new economy firms explain that they have insufficient resources to implement management control. In addition, it was shown that there is only limited need for results control instruments such as product or customer cost and profitability analysis as, in particular, headcount is by far the highest cost driver due to the high $R \& D$ intensity in these firms, and as sales are hardly predictable due to the high uncertainty (Granlund and Taipaleenmäki 2005).

However, results control not only provides financial constraints but is also able to deliver useful wider information for innovative companies. For instance, an emphasis on product innovation or customer satisfaction can be supported by the use of non-financial performance measures (Baines and Langfield-Smith 2003), and Janssen et al. (2011) confirm the usefulness of a balanced set of innovation metrics in tracking R\&D activities. Still, problems concerning measurement of innovation outputs have been reported by several studies (Randle and Rainnie 1997; Kerssens-van Drongelen and Bilderbeek 1999; Hertenstein and Platt 2000).

As another facet of innovation capability, specific results control techniques have been shown to be of relevance for managing collaborations, but the analysis of open-book accounting in networks of Kajüter and Kulmala (2005) and performance information (Mahama 2006) only concerned functional instead of innovative products. Further, in an R\&D 
collaboration setting it was shown that the application of complete formalized target costing schemes did not fit into the technology-driven environment of suppliers (Mouritsen et al. 2001). The adoption of open-book accounting in a collaboration of innovative firms resulted in increased standardization of production and thereby decreasing individuality and speciality of the products (Mouritsen et al. 2001) which might be problematic to innovation companies.

The performance effect of results control in $R \& D$ settings was subject to several studies: Cardinal (2001) reveals positive effects on incremental and radical innovation whereas later studies of Bonner et al. (2002) and Bisbe and Otley (2004) report no significant effects of results control on innovation. Overall, it seems that results control is not appropriate for companies with high innovation capability, because it "encourages low-risk activities, such as competence exploitation and incremental innovations” (Atuahene-Gima 2005, p. 66). If results control is used in an highly innovative setting, employees would bear a high proportion of the risk and would therefore adopt a risk-averse behavior (Atuahene-Gima 2005).

In summary, although acknowledging the role of results control for companies that strive for innovations, it is expected that,

H9a: The extent of results control is negatively associated with the extent of innovation capability of an innovation company.

Activities concerning the generation of innovations or networking with external partners are not readily standardised into prescribed rules and procedures and hence action control is often not applicable (Merchant 1985b). In addition Randle and Rainnie (1997) warn that an attempt to codify and strictly control scientific behaviour runs the risk of hampering creativity and commitment. In contrast, Dekker (2004) stressed the role of action control for managing inter-organisational cooperation as another component of innovation capability. However, the innovation cooperation in the case study discussed by Dekker (2004) focusses on cost reduction and therefore is of incremental nature. Still, the first component of innovation capability, the ability to generate product and process innovations, is expected to suffer from high levels of action control. High formalisation will, as March and Simon (1958) maintain, hinder experimentation. Thus, it is predicted that:

H9b: The extent of action control is negatively associated with the extent of innovation capability of an innovation company. 
Creative and competent human resources is, as the literature maintains, a crucial requirement for innovative companies (Thompson 1970; Randle and Rainnie 1997). It has been confirmed that highly innovative companies train their staff the most (Freel 2005) and personnel control has a positive impact on the likelihood of radical and incremental innovation (Cardinal 2001). Since the importance of personnel control to the generating of innovations seems to be generally accepted, it is hypothesised:

H9c: The extent of personnel control is positively associated with the extent of innovation capability of an innovation company.

Organisational culture is an important element of innovation-intensive firms. Loyalty of professionals is crucial since otherwise the main resource - knowledge - may leave the company (Alvesson 2000; Kunda 2006). Additionally, a strong organisational culture is important as it serves as a knowledge repository and enhances innovative capacity (Lemon and Sahota 2004). Collective action and the ability to reconcile or tolerate dissimilar opinions and values is needed for the generation of innovations (Dougherty 1992) which can be realised through enhanced cultural control. Thus, it is expected that management of companies striving for innovations will tend to apply more instruments in order to foster cultural control.

H9d: The active promotion of cultural control is positively associated with the extent of innovation capability of an innovation company.

\subsubsection{Venture capital and categories of MCSs}

Venture capitalists need to exert control from a distance especially when they are not part of the management board (Jeng and Wells 2000). In addition, venture capital financing has been shown to be associated with a strong short-term interest of the financiers (Granlund and Taipaleenmäki 2005). Therefore results control is appropriate in order to ensure that tasks are accomplished as agreed on and that organisational members strive for the achievement of organisational objectives. It has been shown that venture capitalists use their power over their investee's management in order to influence the type of information they receive, its quality and frequency (Sweeting 1991; Mitchell et al. 1995; Wright and Robbie 1996). Furthermore it has been reported that VC financing is positively related to the use of financial budgets (Bruining et al. 2004), operating and cash budgets (Davila and Foster 2005) and more frequent reporting (Robbie et al. 1997; Bruining et al. 2004). It is therefore hypothesised that, 
H10a: The extent of results control is positively associated with the extent of venture capital funding.

Even in the absence of direct influence of venture capitalists on operations, a company will still need to monitor its processes. Interestingly, Sapienza (1992) showed that for high innovation ventures the more frequent the contact between the venture capitalist and the CEO and the more open the communication was, the more the company benefited from the VC financing. Also Baron and Hannan (2002) confirm that there is a stronger or earlier tendency to bureaucratise in high-tech start-up companies that are VC-backed. As another argument for a stronger application of action control, as is the case for results control, it is expected that the investee management experiences external pressure to formalise control and to cope with a perceived loss of control (Mitchell et al. 1997). Thus,

H10b: The extent of action control is positively associated with the extent of venture capital funding.

Furthermore, it has been shown that venture capitalists also drive professionalization of funded companies as they have a strong influence on HR policies (Hellmann and Puri 2002). Gompers and Learner (2001) argue that venture capitalists play a key role in developing their investee's human resource management, for example by hiring key executives or replacement of managers. VC funding also led to a faster time-to-hiring of financial managers (Davila and Foster 2005). It has also been shown that VC financing has a positive impact on the replacement of the founder by a CEO (Davila 2005). Hence it is expected that,

H10c: The extent of personnel control is positively associated with the extent of venture capital funding.

Of the four categories of control systems, cultural controls are not anticipated to be significantly affected. This is because VC, understood as a short- to medium term source of finance in this framework, is not expected to require the development of shared values and hence there will be less promotion of cultural control. Therefore no hypotheses are derived for this category of MCS. 


\subsubsection{Public funding and categories of MCSs}

To the authors' best knowledge, public funding has so far not been modelled as a contingency factor in MCS research. ${ }^{16}$ Therefore, the following hypotheses are based on general requirements for receiving public funding, and specifically on guidelines in Germany ${ }^{17}$. The application criteria for public funding schemes guide companies towards an increased focus on cost data and project milestones. A detailed forecast of project costs and a project plan has to be submitted. ${ }^{18}$ The obligation to retain project documents for a longer period of time allows past data to inform planning and controlling of current and future projects. Hence results control in innovation companies is encouraged. It is therefore hypothesised that,

H11a: The extent of results control in innovation companies is positively associated with the extent of financial support from public sector sources.

Furthermore, project plans with specific task competencies have to be developed. Using data stored in the retained past project documents, it is possible to formulate procedure guides in order to coordinate future projects. Therefore it is expected that,

H11b: The extent of action control in innovation companies is positively associated with the extent of financial support from public sector sources.

In subsidised innovation projects there is also a strong focus on the skills and knowledge of the personnel who will run the project. Public support in most countries may be expected to require that the projects being considered will demonstrably be "in the public interest". In particular, such projects may be justified by the stimulus that they may have in economically depressed regions, and the improvement in employee skills, education and training that will persist and spread. For governments to be satisfied that such benefits are really being created they are likely to require minimum standards of training, quality and control techniques to ensure they are achieved and can be evidenced. For example, in Germany, in order to verify

\footnotetext{
16 The importance of the contingency factor "public funding” has been identified during the preliminary qualitative study (see Section 2.2.3) and the hypotheses are supplemented by these observations.

17 Guidelines in other countries are believed to be similar, given EU legislation.

18 For this framework, the standard application form (version 3.04 as of 04.09.2013) of the Central Innovation Programme SMEs for individual project funding in Germany has been used to assess the application requirement for public funding (attachment 4 of the application form). http://www.zim-bmwi.de/download/einzelprojekte/antrag_ep_druck, last access 15.09.2013.
} 
sufficient technological and professional skills, education and training certificates have to be provided. Therefore it is hypothesised that:

H11c: The extent of personnel control in innovation companies is positively associated with the extent of financial support from public sector sources.

Public funding is only available to companies which adhere to funding regulations, deliver project certificates after completion and show compliance during the project term. Companies which fail to comply run the risk of being excluded from future funding. Hence it is important that employees comply with the project rules and treat public resources carefully. This may also lead to the development of a set of common (shared) values which control the behaviour of colleagues. Also the instruments of cultural control, like the mission statement, can be used to engage external stakeholders such as the government who subsidized a project (Klemm et al. 1991). It can therefore be expected that:

H11d: The active promotion of cultural control in innovation companies is positively associated with the extent of financial support from public sector sources.

\section{Summary and conclusion}

A summary of the hypotheses derived above shows a mixed picture regarding the emphasis placed by innovation companies on the four MCS categories. Over recent years research has acknowledged the beneficial role that MCSs can play in innovation companies. The relationships hypothesised by this paper's framework are summarised in Table 2 below. 
Table 2 Summary of the framework

\begin{tabular}{|c|c|c|c|c|c|}
\hline & \multirow[b]{2}{*}{ Contingency factors } & \multicolumn{2}{|c|}{ Direct control types } & \multicolumn{2}{|c|}{ Indirect control types } \\
\hline & & Results & Action & Personnel & Cultural \\
\hline \multirow{2}{*}{ 离 } & Environmental uncertainty & + & - & + & + \\
\hline & Customer power & + & + & + & + \\
\hline \multirow{6}{*}{ 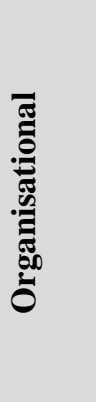 } & Differentiation vs. cost leadership & $<$ & $<$ & $>$ & $>$ \\
\hline & Technological complexity & - & - & + & + \\
\hline & Decentralisation & + & - & + & + \\
\hline & Ownership dispersion & + & + & + & + \\
\hline & Firm size & + & + & + & + \\
\hline & Organisational maturity & + & + & + & + \\
\hline \multirow{3}{*}{ 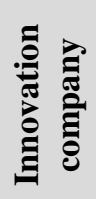 } & Innovation capability & - & - & + & + \\
\hline & Venture capital financing & + & + & + & $\begin{array}{c}\text { not } \\
\text { hypothesized }\end{array}$ \\
\hline & Public funding & + & + & + & + \\
\hline
\end{tabular}

Expected relationships: + positive - negative

$<$ impact of differentiation strategy is weaker than of cost leadership

$>$ impact of differentiation strategy is stronger than of cost leadership

The proposed framework suggests that for innovation companies, particular attention should be devoted to the design of management control. For the direct types of control, results and action control, the 'message' is not straightforward. While for most of the eleven contingency factors a positive impact on the use of results control is hypothesised, two potential contingencies are anticipated to have a negative association: technological complexity and innovation capability. Hence, in particular results control instruments such as performance measures (e.g. ROI, inventory control, quality measures), budgets, and reward structures should be carefully chosen. Likewise, intense action control by applying e.g. procedure guides, operating manuals, physical or administrative constraints needs to be handled carefully in innovation companies as four contingency factors are expected to be negatively associated with this type of control. For business strategy, it is expected that cost leaders will apply both types of direct control more intensively than will differentiators.

Strikingly, for all eleven contingency factors a positive impact on the indirect types of control, namely personnel and cultural control, is predicted ${ }^{19}$. Hence personnel control with its focus on employee selection, job design, training and development, and active promotion

19 Except for a not hypothesized effect of VC on cultural control. 
of cultural control by establishing shared values through e.g. codes of conduct, team rewards are of particular use for managers of innovation companies to guide employees towards organisational goals given different contingencies.

Overall, the non-uniform and nuanced nature of this framework is supported by the MCS literature. It shows that the MCS categories do not work in isolation (Abernethy and Chua 1996; Gerdin 2005). By the early 1980s Otley (1980) and Flamholtz (1983) had recognized that direct controls are only effective if they are accompanied by indirect types of control. In particular innovation companies require indirect controls in order to retain, and support, flexibility and creativity.

Overall, indirect controls seem to be better suited to the specific contingencies faced by innovation companies. The focus of personnel and cultural control is on enabling employees to control themselves and others in their team. Indirect controls aim to activate self and group control within the company. In contrast, the direct and more formal types of control, results and action control, can be interpreted by employees as boundaries and hence hamper innovativeness and creativity.

Of course, it is important that this theoretical framework is tested empirically in order to reveal whether the suggested eleven contingency factors are relevant for the innovation company setting at all whether the hypothesised relationships also hold in practice and what the extent of the significant relationships is. Even if an empirical investigation would reveal conflicting contingencies that are of relevance for a certain company, from the extent of the significant path coefficients, a manager would be able to decide whether a certain control category should be intensified or rather decreased. This framework helps in summing up the different control papers discussing single control instruments and few contingency factors and is therefore of interest for an empirical investigation.

From a managerial perspective, the framework does not deliver a clear-cut guideline about which control types should be applied. However, contingency is not about proposing a onebest control system for all innovation companies, but has to be viewed in the context of the specific circumstances faced by a company. The design of the control system is a managerial choice, and underlies the concept of contingency theory's 'selection approach'. For further research, it is important to correctly classify specific controls in order to be able to prescribe which components of results and action control may need to be limited in innovation companies.

This paper adds to the literature on motivations for adoption of MCSs by identifying and structuring specific factors which are expected to lead to more intensified use of four types of 
controls. The insights derived, especially if supported by empirical evidence, will have value for managers of all companies but especially for those of innovation companies. Managers may have an incentive to intensify or adapt their MCS in order to better respond to the specific circumstances their company faces. In addition there are potential policy implications for innovation networks and broader institutional bodies.

\section{References}

Abdel-Kader, M. \& Luther, R. (2008). The impact of firm characteristics on management accounting practices: A UK-based empirical analysis. The British Accounting Review, 40(1), 2-27.

Abernethy, M. A. \& Chua, W. F. (1996). A field study of control system "redesign": The impact of institutional processes on strategic choice. Contemporary Accounting Research, 13(2), 569-606.

Abernethy, M. A. \& Brownell, P. (1997). Management control systems in research and development organizations: The role of accounting, behavior and personnel controls. Accounting, Organizations \& Society, 22(3/4), 233-248.

Abernethy, M. A., Bouwens, J. \& van Lent, L. (2004). Determinants of control system design in divisionalized firms. Accounting Review, 79(3), 545-570.

Adami, L. M. (1999). Autonomy, control and the virtual worker. in: Virtual Working: social and organisational dynamics. Jackson, P. L. Routledge: London. pp. 131-150.

Adler, P. S. \& Borys, B. (1996). Two types of bureaucracy: Enabling and coercive. Administrative Science Quarterly, 41(1), 61-89.

Alvesson, M. (1993a). Cultural-ideological modes of control. Communication Yearbook, 16, 3-42.

Alvesson, M. (1993b). Organizations as rhetoric: Knowledge-intensive firms and the struggle with ambiguity. Journal of Management Studies, 30(6), 997-1015.

Alvesson, M. (2000). Social identity and the problem of loyalty in knowledge-intensive companies. Journal of Management Studies, 37(8), 1101-1123.

Alvesson, M. \& Kärreman, D. (2004). Interfaces of control. Technocratic and socio-ideological control in a global management consultancy firm. Accounting, Organizations and Society, 29(3-4), 423-444.

Amabile, T. M. (1998). How to kill creativity. Harvard Business Review, 76(5), 76-87.

Analoui, F. (2001). What motivates senior managers?: The case of Romania. Journal of Managerial Psychology 15(4), 324-340.

Anthony, R. N. \& Govindarajan, V. (2007). Management Control Systems. New York et al.: Irwin/Mc Graw Hill. 12th ed.

Arthur, J. B. (1992). The link between business strategy and industrial relations systems in American steel minimills. Industrial \& Labor Relations Review, 45(3), 488-506.

Atuahene-Gima, K. (2005). Resolving the capability-rigidity paradox in new product innovation. Journal of Marketing, 69(October 2005), 61-83.

Auzair, S. M. \& Langfield-Smith, K. (2005). The effect of service process type, business strategy and life cycle stage on bureaucratic MCS in service organizations. Management Accounting Research, 16(4), 399421.

Bahrami, H. \& Evans, S. (2000). Flexible recycling and high-technology entrepreneurship. in: Understanding Silicon Valley: The anatomy of an entrepreneurial region. Kennedy, M. Stanford: Stanford University Press. 165-189.

Baines, A. \& Langfield-Smith, K. (2003). Antecedents to management accounting change: A structural equation approach. Accounting, Organizations and Society, 28(7-8), 675-698.

Baliga, B. R. \& Jaeger, A. M. (1984). Multinational corporations: Control systems and delegation issues. Journal of International Business Studies, 15(2), 25-40.

Baptista, R. \& Swann, P. (1998). Do firms in clusters innovate more? Research Policy, 27, 525-540.

Baron, J. N. \& Hannan, M. T. (2002). Organizational blueprints for success in high-tech start-ups: Lessons from the Stanford project on emerging companies. California Management Review, 44(3), 8-36.

Bart, C. K. (1993). General managers control new and existing products differently. Journal of Business Venturing, 8(4), 341-361.

Beaudry, C. \& Breschi, S. (2003). Are firms in clusters really more innovative? Economics of Innovation \& New Technology, 12(4), 325-342. 
Bisbe, J. \& Otley, D. (2004). The effects of the interactive use of management control systems on product innovation. Accounting, Organizations \& Society, 29(8), 709-737.

Bonner, J. M., Ruekert, R. W. \& Walker Jr, O. C. (2002). Upper management control of new product development projects and project performance. Journal of Product Innovation Management, 19(3), 233245.

Bonner, J. M. (2005). The influence of formal controls on customer interactivity in new product development. Industrial Marketing Management, 34(1), 63-69.

Brown, A., Wiele, T. v. d. \& Loughton, K. (1998). Smaller enterprises' experiences with ISO 9000. International Journal of Quality \& Reliability Management, 15(3), 273-285.

Bruggeman, W. \& Van der Stede, W. (1993). Fitting management control systems to competitive advantage. British Journal of Management, 4(3), 205-218.

Bruining, H., Bonnet, M. \& Wright, M. (2004). Management control systems and strategy change in buyouts. Management Accounting Research, 15(2), 155-177.

Bruns, W. J. \& Waterhouse, J. H. (1975). Budgetary control and organization structure. Journal of Accounting Research, 13(2), 177-203.

Burns, T. \& Stalker, G. (1961). The management of innovation. London: Tavistock.

Carbonell, P. \& Rodriguez, A. I. (2006). Designing teams for speedy product development: The moderating effect of technological complexity. Journal of Business Research, 59(2), 225-232.

Cardinal, L. B. (2001). Technological innovation in the pharmaceutical industry: The use of organizational control in managing research and development. Organization Science, 12(1), 19-36.

Carr, C. \& Tomkins, C. (1996). Strategic investment decisions: the importance of SCM. A comparative analysis of 51 case studies in U.K., U.S. and German companies. Management Accounting Research, 7(2), 199-217.

Chapman, C. S. (1997). Reflections on a contingent view of accounting. Accounting, Organizations and Society, 22(2), 189-205.

Chenhall, R. H. \& Morris, D. (1986). The impact of structure, environment, and interdependence on the perceived usefulness of management accounting systems. Accounting Review, 61(1), 16-35.

Chenhall, R. H. \& Langfield-Smith, K. (1998). The relationship between strategic priorities, management techniques and management accounting: An empirical investigation using a systems approach. Accounting, Organizations and Society, 23(3), 243-264.

Chenhall, R. H. (2003). Management control systems design within its organizational context: Findings from contingency-based research and directions for the future. Accounting, Organizations \& Society, 28(2/3), 127-168.

Chenhall, R. H. (2005). Integrative strategic performance measurement systems, strategic alignment of manufacturing, learning and strategic outcomes: an exploratory study. Accounting, Organizations and Society, 30(5), 395-422.

Child, J. (1973a). Strategies of control and organizational behavior. Administrative Science Quarterly, 18(1), 117.

Child, J. (1973b). Predicting and understanding organization structure. Administrative Science Quarterly, 18(2), 168-185.

Chong, V. K. \& Chong, K. M. (1997). Strategic choices, environmental uncertainty and SBU performance: A note on the intervening role of management accounting systems. Accounting \& Business Research, 27(4), 268-276.

Chow, C. W., Shields, M. D. \& Wu, A. (1999). The importance of national culture in the design of and preference for management controls for multi-national operations. Accounting, Organizations and Society, 24(5-6), 441-461.

Chow, I. H. S. \& Gong, Y. (2010). The linkage of HRM and knowledge-related performance in China's technology-intensive industries. International Journal of Human Resource Management, 21(8), 1289-1306.

Collier, P. M. (2005). Entrepreneurial control and the construction of a relevant accounting. Management Accounting Research, 16(3), 321-339.

Collins, F., Holzmann, O. \& Mendoza, R. (1997). Strategy, budgeting, and crisis in Latin America. Accounting, Organizations and Society, 22(7), 669-689.

Cousins, P. D., Handfield, R. B., Lawson, B. \& Petersen, K. J. (2006). Creating supply chain relational capital: The impact of formal and informal socialization processes. Journal of Operations Management, 24(6), 851-863.

Cousins, P. D. \& Menguc, B. (2006). The implications of socialization and integration in supply chain management. Journal of Operations Management, 24(5), 604-620.

Damanpour, F. (1991). Organizational innovation: A meta-analysis of effects of determinants and moderators. Academy of Management Journal, 34(3), 555-590. 
Davila, A. (2000). An empirical study on the drivers of management control systems' design in new product development. Accounting, Organizations \& Society, 25(4/5), 383-409.

Davila, A. (2005). An exploratory study on the emergence of management control systems: Formalizing human resources in small growing firms. Accounting, Organizations and Society, 30(3), 223-248.

Davila, A. \& Foster, G. (2005). Management accounting systems adoption decisions: Evidence and performance implications from early-stage/startup companies. Accounting Review, 80(4), 1039-1068.

Davila, A. \& Foster, G. (2007). Management control systems in early-stage startup companies. Accounting Review, 82(4), 907-937.

Davila, A., Foster, G. \& Li, M. (2009). Reasons for management control systems adoption: Insights from product development systems choice by early-stage entrepreneurial companies. Accounting, Organizations and Society, 34(3-4), 322-347.

Dekker, H. C. (2004). Control of inter-organizational relationships: Evidence on appropriation concerns and coordination requirements. Accounting, Organizations and Society, 29-47(1), 27-49.

Dent, J. F. (1990). Strategy, organization and control: Some possibilities for accounting research. Accounting, Organizations and Society, 15(1-2), 3-25.

Ditillo, A. (2004). Dealing with uncertainty in knowledge-intensive firms: The role of management control systems as knowledge integration mechanisms. Accounting, Organizations and Society, 29(3/4), 401-421.

Donaldson, L. (2001). The contingency theory of organizations. Thousand Oaks: Sage.

Dougherty, D. (1992). Interpretive barriers to successful product innovation in large firms. Organization Science, 3(2), 179-202.

Drazin, R. \& Van De Ven, A. H. (1985). Alternative forms of fit in contingency theory. Administrative Science Quarterly, 30(4), 514-539.

Drury, C. (2008). Management and cost accounting. London: South Western. 7th ed.

Dunk, A. S. (1992). Reliance on budgetary control, manufacturing process automation and production subunit performance: A research note. Accounting, Organizations and Society, 17(3-4), 195-203.

Enright, M. (2003). Regional clusters: What we know and what we should know. in: Innovation clusters and interregional competition. Bröcker, J., Dohse, D. \& Soltwedel, R. Berlin: Springer

Ferreira, A. \& Otley, D. (2009). The design and use of performance management systems: an extended framework for analysis. Management Accounting Research, 20(4), 263-282.

Ferreira, A. \& Otley, D. (2010). Design and use of management control systems: An analysis of the interaction between design misfit and intensity of use. Working paper, CIPFA, London.

Fisher, C. (1996). The impact of perceived environmental uncertainty and individual differences on management information requirements: A research note. Accounting, Organizations and Society, 21(4), 361-369.

Fisher, J. (1995). Contingency-based research on management control systems: Categorization by level of complexity. Journal of Accounting Literature, 14, 24-48.

Fisher, J. (1998). Contingency theory, management control systems and firm outcomes: Past results and future directions. Behavioral Research in Accounting, 10(Supplement), 47-64.

Flamholtz, E. G. (1983). Accounting, budgeting and control systems in their organizational context: theoretical and empirical perspectives. Accounting, Organizations and Society, 8(2-3), 153-169.

Freel, M. S. (2005). Patterns of innovation and skills in small firms. Technovation, 25(2), 123-134.

Fuentes-Fuentes, M. M., Lloréns-Montes, F. J. \& Albacete-Sáez, C. A. (2007). Quality management implementation across different scenarios of competitive structure: An empirical investigation. International Journal of Production Research, 45(13), 2975-2995.

Gerdin, J. (2005). Management accounting system design in manufacturing departments: An empirical investigation using a multiple contingencies approach. Accounting, Organizations and Society, 30(2), 99126.

Gilbert, X. \& Strebel, P. (1987). Strategies to outpace the competition. Journal of Business Strategy, 8(1), pp. 28-36.

Gompers, P. \& Lerner, J. (2001). The venture capital revolution. Journal of Economic Perspectives, 15(2), $145-168$.

Gordon, L. A. \& Narayanan, V. K. (1984). Management accounting systems, perceived environmental uncertainty and organization structure: An empirical investigation. Accounting, Organizations and Society, 9(1), 33-47.

Govindarajan, V. (1984). Appropriateness of accounting data in performance evaluation: An empirical examination of environmental uncertainty as an intervening variable. Accounting, Organizations and Society, 9(2), 125-135.

Govindarajan, V. (1988). A contingency approach to strategy implementation at the business-unit level: Integrating administrative mechanisms with strategy. Academy of Management Journal, 31(4), 828-853. 
Govindarajan, V. \& Fisher, J. (1990). Strategy, control systems, and resource sharing: Effects on business-unit performance. Academy of Management Journal, 33(2), 259-285.

Granlund, M. \& Taipaleenmäki, J. (2005). Management control and controllership in new economy firms - A life cycle perspective. Management Accounting Research, 16(1), 21-57.

Grugulis, I., Dundon, T. \& Wilkinson, A. (2000). Cultural control and the 'culture manager': Employment practices in a consultancy. Work, Employment \& Society, 14(1), 97-116.

Guenther, T. (2013). Conceptualisations of 'controlling' in German-speaking countries: analysis and comparison with Anglo-American management control frameworks. Journal of Management Control, 23(4), 269-290.

Guilding, C. \& McManus, L. (2002). The incidence, perceived merit and antecedents of customer accounting: An exploratory note. Accounting, Organizations and Society, 27(1-2), 45-59.

Gul, F. A. (1991). The effects of management accounting systems and environmental uncertainty on small business managers' performance. Accounting \& Business Research, 22(85), 57-61.

Guler, I., Guillén, M. F. \& Macpherson, J. M. (2002). Global competition, institutions, and the diffusion of organizational practices: The international spread of ISO 9000 quality certificates. Administrative Science Quarterly, 47(2), 207-232.

Gupta, A. K. \& Govindarajan, V. (1984). Business unit strategy, managerial characteristics, and business unit effectiveness at strategy implementation. Academy of Management Journal, 27(1), 25-41.

Gupta, A. K. \& Govindarajan, V. (2000). Knowledge flows within multinational corporations. Strategic Management Journal, 21(4), 473-496.

Gupta, Y. P. \& Chin, D. C. W. (1991). An empirical examination of information systems expenditure: A stage hypothesis using the information processing and organizational life cycle approaches. Journal of Information Science, 17(2), 105-117.

Hamel, G. \& Prahalad, C. K. (1994). Competing for the future. Cambridge: Harvard University Press.

Harrison, G. L. (1993). Reliance on accounting performance measures in superior evaluative style - The influence of national culture and personality. Accounting, Organizations and Society, 18(4), 319-339.

Hartmann, F. G. (2000). The appropriateness of RAPM: Toward the further development of theory. Accounting, Organizations and Society, 25(4-5), 451-482.

Hayes, R. H., Wheelwright, S. C. \& Clark, K. B. (1988). Dynamic manufacturing: Creating the learning organization. New York: Free Press.

Hellmann, T. \& Puri, M. (2002). Venture capital and the professionalization of start-up firms: Empirical evidence. Journal of Finance, 57(1), 169-197.

Hertenstein, J. H. \& Platt, M. B. (2000). Performance measures and management control in new product development. Accounting Horizons, 14(3), 303-323.

Hill, C. W. L. \& Hoskisson, R. E. (1987). Strategy and structure in the multiproduct firm. Academy of Management Review, 12(2), 331-341.

Hirst, M. K. (1981). Accounting information and the evaluation of subordinate performance: A situational approach. Accounting Review, 56(4), 771-784.

Holthausen, R. W., Larcker, D. F. \& Sloan, R. G. (1995). Business unit innovation and the structure of executive compensation. Journal of Accounting \& Economics, 19(2/3), 279-313.

Hopwood, A. G. (1974). Leadership climate and the use of accounting data in performance evaluation. Accounting Review, 49(3), 485-495.

Hopwood, A. G. (1976). Accounting and human behavior. Englewood Cliffs: Prentice Hall.

Hoque, Z. \& James, W. (2000). Linking balanced scorecard measures to size and market factors: Impact on organizational performance. Journal of Management Accounting Research, 12, 1-17.

Hoskisson, R. E., Hitt, M. A. \& Ireland, R. D. (1990). Mergers and acquisitions and managerial commitment to innovation in m-form firms. Strategic Management Journal, 11, 29-48.

Howorth, C. \& Westhead, P. (2003). The focus of working capital management in UK small firms. Management Accounting Research, 14(2), 94-111.

Hult, G. T. M., Hurley, R. F. \& Knight, G. A. (2004). Innovativeness: Its antecedents and impact on business performance. Industrial Marketing Management, 33(5), 429-438.

Hurley, R. F. \& Hult, G. T. M. (1998). Innovation, market orientation, and organizational learning: An integration and empirical examination. Journal of Marketing, 62(3), 42-54.

Hutzschenreuter, T. (2009). Management control in small and medium-sized enterprises. Wiesbaden: Gabler.

Janssen, S., Moeller, K. \& Schlaefke, M. (2011). Using performance measures conceptually in innovation control. Journal of Management Control, 22(1), 107-128.

Jaworski, B. J. (1988). Toward a theory of marketing control: environmental context, control types, and consequences. Journal of Marketing, 52(3), 23-39.

Jeng, L. A. \& Wells, P. C. (2000). The determinants of venture capital funding: Evidence across countries. Journal of Corporate Finance, 6(3), 241-289. 
Johannisson, B. \& Huse, M. (2000). Recruiting outside board members in the small family business: An ideological challenge. Entrepreneurship \& Regional Development, 12(4), 353-378.

Jones, C. S. (1992). The attitudes of owner-managers towards accounting control systems following management buyout. Accounting, Organizations and Society, 17(2), 151-168.

Jørgensen, B. \& Messner, M. (2009). Management Control in New Product Development: The Dynamics of Managing Flexibility and Efficiency. Journal of Management Accounting Research, 21, 99-124.

Kajüter, P. \& Kulmala, H. I. (2005). Open-book accounting in networks: Potential achievements and reasons for failures. Management Accounting Research, 16(2), 179-204.

Kamin, J. Y. \& Ronen, J. (1978). The smoothing of income numbers: Some empirical evidence on systematic differences among management-controlled and owner-controlled firms. Accounting, Organizations and Society, 3(2), 141-157.

Kärreman, D., Sveningsson, S. \& Alvesson, M. (2002). The return of the machine bureaucracy? Management control in the work settings of professionals. International Studies of Management \& Organization, 32(2), 70-92.

Kazanjian, R. K. (1988). Relation of dominant problems to stages growth in technology-based new ventures. Academy of Management Journal, 31(2), 257-279.

Kelly, T. \& Gosman, M. (2000). Increased buyer concentration and its effects on profitability in the manufacturing sector. Review of Industrial Organization, 17(1), 41-59.

Kerssens-van Drongelen, I. C. \& Bilderbeek, J. (1999). R\&D performance measurement: More than choosing a set of metrics. $R \& D$ Management, 29(1), 35-46.

Khandwalla, P. N. (1972). The effect of different types of competition on the use of management controls. Journal of Accounting Research, 10(2), 275-285.

Khandwalla, P. N. (1977). The design of organizations. New York: Harcourt Brace Jovanovich.

Kimberly, J. A. (1976). Organizational size and the structuralist perspective: A review, critique, and proposal. Administrative Science Quarterly, 21(4), 571-597.

Klemm, M., Sanderson, S. \& Luffman, G. (1991). Mission statements: Selling corporate values to employees. Long Range Planning, 24(3), 73-78.

Kloot, L. (1997). Organizational learning and management control systems: responding to environmental change. Management Accounting Research, 8(1), 47-73.

Kunda, G. (2006). Engineering culture: Control and commitment in a high-tech corporation. Philadelphia: Temple University Press. revised ed.

Langfield-Smith, K. (1997). Management control systems and strategy: A critical review. Accounting, Organizations and Society, 22(2), 207-232.

Lawrence, P. \& Lorsch, J. (1967). Organization and environment. Homewood: Irwin.

Lemon, M. \& Sahota, P. S. (2004). Organizational culture as a knowledge repository for increased innovative capacity. Technovation, 24(6), 483-498.

Luft, J. \& Shields, M. D. (2003). Mapping management accounting: graphics and guidelines for theoryconsistent empirical research. Accounting, Organizations and Society, 28(2-3), 169-249.

Lukka, K. \& Granlund, M. (2003). Paradoxes of management and control in a new economy firm. in: Management accounting in the digital economy. Bhimani, A. Oxford: Oxford University Press. 239-259.

Macintosh, N. B. \& Williams, J. J. (1992). Managerial roles and budgeting behavior. Behavioral Research in Accounting, 4, 23-48.

Mahama, H. (2006). Management control systems, cooperation and performance in strategic supply relationships: A survey in the mines. Management Accounting Research, 17(3), 315-339.

Malmi, T. \& Brown, D. A. (2008). Management control systems as a package--Opportunities, challenges and research directions. Management Accounting Research, 19(4), 287-300.

March, J. G. \& Simon, H. A. (1958). Organizations. New York: Wiley.

Martínez-Román, J. A., Gamero, J. \& Tamayo, J. A. (2011). Analysis of innovation in SMEs using an innovative capability-based non-linear model: A study in the province of Seville (Spain). Technovation, 31(9), 459-475.

Merchant, K. A. (1981). The design of the corporate budgeting system: Influences on managerial behavior and performance. Accounting Review, 56(4), 813-829.

Merchant, K. A. (1984). Influences on departmental budgeting: An empirical examination of a contingency model. Accounting, Organizations and Society, 9(3-4), 291-307.

Merchant, K. A. (1985a). Budgeting and the propensity to create budgetary slack. Accounting, Organizations and Society, 10(2), 201-210.

Merchant, K. A. (1985b). Control in business organizations. Cambridge: Ballinger.

Merchant, K. A. (1990). The effects of financial controls on data manipulation and management Myopia. Accounting, Organizations and Society, 15(4), 297-313.

Merchant, K. A. (1997). Modern management control systems. Upper Saddle River: Prentice Hall. 
Merchant, K. A. \& Otley, D. (2007). A review on the literature on control and accountability. in: Handbook of management accounting research. Chapman, C., Hopwood, A. G. \& Shields, M. D. Amsterdam et al.: Elsevier. Vol 2. 785-802.

Merchant, K. A. \& Van der Stede, W. A. (2012). Management control systems: Performance measurement, evaluation and incentives. Harlow et al.: Pearson Education. 3rd ed.

Miles, R. E. \& Snow, C. C. (1978). Organizational strategy, structure, and process. New York: McGraw-Hill. Reprinted in 2003, Stanford: Stanford University Press.

Miles, R. E., Snow, C. C., Meyer, A. D. \& Coleman, J. H. J. (1978). Organizational strategy, structure, and process. Academy of Management Review, 3(3), 546-562.

Miller, D. \& Friesen, P. H. (1983). Successful and unsuccessful phases of the corporate life cycle. Organization Studies, 4(4), 339-356.

Miller, D. \& Friesen, P. H. (1984). A longitudinal study of the corporate life cycle. Management Science, 30(10), 1161-1183.

Mitchell, F., Reid, G. C. \& Terry, N. G. (1995). Post investment demand for accounting information by venture capitalists. Accounting \& Business Research, 25(99), 186-196.

Mitchell, F., Reid, G. C. \& Terry, N. G. (1997). Venture capital supply and accounting information system development. Entrepreneurship: Theory \& Practice, 21(4), 45-62.

Moores, K. \& Yuen, S. (2001). Management accounting systems and organizational configuration: A life-cycle perspective. Accounting, Organizations and Society, 26(4-5), 351-389.

Mouritsen, J., Hansen, A. \& Hansen, C. Ø. (2001). Inter-organizational controls and organizational competencies: Episodes around target cost management/functional analysis and open book accounting. Management Accounting Research, 12(2), 221-244.

Nanda, V. (2005). Quality management system handbook for product development companies. Boca Raton: CRC Press.

Nassimbeni, G. (2001). Technology, innovation capacity, and the export attitude of small manufacturing firms: A logit/tobit model. Research Policy, 30(2), 245-262.

Nixon, B. (1998). Research and development performance measurement: A case study. Management Accounting Research, 9(3), 329-355.

Nonaka, I. \& Takeuchi, H. (1995). The knowledge-creating company: How Japanese companies create the dynamics of innovation. Oxford: Oxford University Press.

O'Connor, N. G. (1995). The influence of organizational culture on the usefulness of budget participation by Singaporean-Chinese managers. Accounting, Organizations and Society, 20(5), 383-403.

O’Connor, N. G., Deng, J. \& Luo, Y. (2006). Political constraints, organization design and performance measurement in China's state-owned enterprises. Accounting, Organizations and Society, 31(2), 157-177.

O’Connor, N. G., Vera-Muñoz, S. C. \& Chan, F. (2011). Competitive forces and the importance of management control systems in emerging-economy firms: The moderating effect of international market orientation. Accounting, Organizations and Society, 36(4-5), 246-266.

OECD (2002). Frascati Manual 2002: Proposed standard practice for surveys on research and experimental development. Luxembourg: OECD Publishing.

OECD (2005). Oslo Manual: Guidelines for collecting and interpreting innovation data. Luxembourg: OECD, Statistical Office of the European Communities.

Osterman, P. (1994). How common is workplace transformation and who adopts it? Industrial \& Labor Relations Review, 47(2), 173-188.

Otley, D. (1980). The contingency theory of management accounting: Achievement and prognosis. Accounting, Organizations \& Society, 5(4), 413-428.

Otley, D. (1999). Performance management: A framework for management control systems research. Management Accounting Research, 10(4), 363-382.

Ouchi, W. G. (1977). The relationship between organizational structure and organizational control. Administrative Science Quarterly, 22(1), 95-113.

Ouchi, W. G. (1978). The transmission of control through organizational hierarchy. The Academy of Management Journal, 21(2), 173-192.

Ouchi, W. G. (1979). A conceptual framework for the design of organizational control mechanisms. Management Science, 25(9), 833-848.

Ouchi, W. G. (1980). Markets, bureaucracies, and clans. Administrative Science Quarterly, 25(1), 129-141.

Peck, S. R. (1994). Exploring the link between organizational strategy and the employment relationship: The role of human resources policies. Journal of Management Studies, 31(5), 715-736.

Perdomo-Ortiz, J., González-Benito, J. \& Galende, J. (2006). Total quality management as a forerunner of business innovation capability. Technovation, 26(10), 1170-1185.

Perrow, C. (1967). A framework for the comparative analysis of organizations. American Sociological Review, 32(2), 194-208. 
Perrow, C. (1970). Organizational analysis: A sociological view. Belmont: Wadsworth Publsihing.

Porter, M. E. (1980). Competitive strategy: Techniques for analysing industries and competitors. New York: The Free Press.

Pugh, D. S., Hickson, D. J., Hinings, C. R. \& Turner, C. (1969). The Context of Organization Structures. Administrative Science Quarterly, 14(1), 91-114.

Randle, K. \& Rainnie, A. (1997). Managing creativity, maintaining control: A study in pharmaceutical research. Human Resource Management Journal, 7(2), 32-46.

Rayner, P. \& Porter, L. J. (1991). BS 5750/ISO 9000 - The experience of small and medium-sized firms. International Journal of Quality and Reliability Management, 8(6), 16-28.

Reeves, T. K. \& Woodward, J. (1970). The study of managerial controls. in: Industrial organization: Behavior and control. Woodward, J. London: Oxford.

Reid, R. S. \& Adams, J. S. (2001). Human resource management - A survey of practices within family and non-family firms. Journal of European Industrial Training, 25(6), 310-320.

Robbie, K., Wright, M. \& Chiplin, B. (1997). The monitoring of venture capital firms. Entrepreneurship: Theory \& Practice, 21(4), 9-28.

Rockness, H. O. \& Shields, M. D. (1988). An empirical analysis of the expenditure budget in research and development. Contemporary Accounting Research, 4(2), 568-581.

Rosenstein, J., Bruno, A. V., Bygrave, W. D. \& Taylor, N. T. (1993). The CEO, venture capitalists, and the board. Journal of Business Venturing, 8(2), 99-113.

Ross, A. (1995). Job related tension, budget emphasis and uncertainty: A research note. Management Accounting Research, 6(1), 1-11.

Sandino, T. (2007). Introducing the first management control systems: Evidence from the retail sector. Accounting Review, 82(1), 265-293.

Santos, L. \& Escanciano, C. (2002). Benefits of the ISO 9000:1994 system: Some considerations to reinforce competitive advantage. International Journal of Quality \& Reliability Management, 19(3), 321-344.

Sapienza, H. J. (1992). When do venture capitalists add value? Journal of Business Venturing, 7(1), 9-27.

Sarin, S. \& Mahajan, V. (2001). The effect of reward structures on the performance of cross-functional product development teams. Journal of Marketing, 65(2), 35-53.

Scherer, F. M. \& Ross, D. (1990). Industrial market structure and economic performance. Boston: Houghton Mifflin. 3rd ed.

Schuler, R. S. (1989). Strategic human resource management and industrial relations. Human Relations, 42(2), 157-184.

Segev, E. (1989). A systematic comparative analysis and synthesis of two business-level strategic typologies. Strategic Management Journal, 10(5), 487-505.

Silvola, H. (2008). Do organizational life-cycle and venture capital investors affect the management control systems used by the firm? Advances in Accounting, 24(1), 128-138.

Simons, R. (1987). Accounting control systems and business strategy: An empirical analysis. Accounting, Organizations \& Society, 12(4), 357-374.

Simons, R. (1995). Levers of control: How managers use innovative control systems to drive strategic renewal. Boston: Harvard Business School Press.

Snell, S. A. (1992). Control theory in strategic human resource management: The mediating effect of administrative information. The Academy of Management Journal, 35(2), 292-327.

Snell, S. A. \& Dean, J. W., Jr. (1992). Integrated manufacturing and human resource management: A human capital perspective. The Academy of Management Journal, 35(3), 467-504.

Speklé, R. F. (2001). Explaining management control structure variety: A transaction cost economics perspective. Accounting, Organizations and Society, 26(4-5), 419-441.

Strauß, E. \& Zecher, C. (2012). Management control systems: a review. Journal of Management Control, 1-36 DOI: $10.1007 / s 00187-012-0158-7$

Sweeting, R. C. (1991). Early-stage new technology-based businesses: Interactions with venture capitalists and the development of accounting techniques and procedures. The British Accounting Review, 23(1), 3-21.

Thompson, G. F. (1970). The management of research and development. London: Batsford.

Thompson, J. D. (1967). Organizations in action: Social science bases of administrative theory. New York: Mc GrawHill, reprinted in 2003: Transaction publications.

Van de Ven, A. H., Delbecq, A. L. \& Koenig, R., Jr. (1976). Determinants of coordination modes within organizations. American Sociological Review, 41(2), 322-338.

Van der Stede, W. A. (2000). The relationship between two consequences of budgetary controls: Budgetary slack creation and managerial short-term orientation. Accounting, Organizations \& Society, 25(6), 609-622.

Vloeberghs, D. \& Bellens, J. (1996). Implementing the ISO 9000 standards in Belgium. Quality Progress, 29(6), 43-48. 
Wan, D., Ong, C. H. \& Lee, F. (2005). Determinants of firm innovation in Singapore. Technovation, 25(3), 261-268.

Weick, K. E. (1987). Organizational culture as a source of high reliability. California Management Review, 29(2), 112-127.

Whitley, R. (1999). Firms, institutions and management control: The comparative analysis of coordination and control systems. Accounting, Organizations and Society, 24(5-6), 507-524.

Wilkins, A. L. \& Ouchi, W. G. (1983). Efficient cultures: Exploring the relationship between culture and organizational performance. Administrative Science Quarterly, 28(3), 468-481.

Wilkinson, B. \& Oliver, N. (1992). The Japanization of British Industry: New Developments in the 1990s. Oxford: Jon Wiley and Sons. 2nd ed.

Williams, C. \& van Triest, S. (2009). The impact of corporate and national cultures on decentralization in multinational corporations. International Business Review, 18(2), 156-167.

Williamson, O. E. (1975). Markets and hierachies: Analysis and antitrust implications. New York: The Free Press.

Woodward, J. (1965). Industrial organization: Theory and practice London: Oxford.

Wright, M. \& Robbie, K. (1996). Venture capitalists, unquoted equity investment appraisal and the role of accounting information. Accounting \& Business Research, 26(2), 153-168.

Yam, R. C. M., Lo, W., Tang, E. P. Y. \& Lau, A. K. W. (2011). Analysis of sources of innovation, technological innovation capabilities, and performance: An empirical study of Hong Kong manufacturing industries. Research Policy, 40(3), 391-402. 